Li Wenjing (Orcid ID: 0000-0001-8091-6470)

\title{
Patients' and caregivers' knowledge and beliefs about mental illness in mainland China: A systematic review
}

\author{
W. Li, PhD, N. Reavley, PhD \\ Centre for Mental Health, Melbourne School of Population and Global Health, The \\ University of Melbourne
}

\section{Correspondence:}

Wenjing LI, PhD

Centre for Mental Health, The University of Melbourne

Level 4, 207 Bouverie Street

Carlton, VIC 3053, Australia

Email: wenjing.li1@unimelb.edu.au

This is the author manuscript accepted for publication and has undergone full peer review but has not been through the copyediting, typesetting, pagination and proofreading process, which may lead to differences between this version and the Version of Record. Please cite this article as doi: 10.1111/appy.12423

This article is protected by copyright. All rights reserved. 
Patients' and caregivers' knowledge and beliefs about mental illness in mainland China: A systematic review

\author{
W. Li, PhD, N. Reavley, PhD \\ Centre for Mental Health, Melbourne School of Population and Global Health, The \\ University of Melbourne
}

Correspondence:

Wenjing LI, PhD

Centre for Mental Health, The University of Melbourne

Level 4, 207 Bouverie Street

Carlton, VIC 3053, Australia

Email: wenjing.li1@unimelb.edu.au

This article is protected by copyright. All rights reserved. 


\begin{abstract}
This review aimed to systematically investigate patients' and caregivers' knowledge and beliefs about mental illness in mainland China. A total of 48 eligible studies $(N=11,895)$ were retrieved from 8 electronic databases. Prevalence statistics were computed for themes (e.g., stress) under each construct relating to knowledge or belief about mental illness (e.g., beliefs about causes). Effect size $r$ was calculated for each correlation with an identified construct. We found that only $27.8 \%$ of patients recognized the symptoms of schizophrenia. Although $65 \%$ of caregivers declared that they knew the names of the disorders that their ill relatives had, depression (43.6\%), schizophrenia (28.5\%) and anxiety disorders (18.1\%) had low recognition rates. Both caregivers and patients preferred psychosocial explanations of mental illness. Pharmacological interventions (e.g., antipsychotics), non-specific actives (e.g., "getting out and learning more”), mental health professionals (e.g., psychiatrists) and informal support (e.g., family) were each considered helpful for different disorders by caregivers, whereas regular contact with mental health professionals was not highly rated as helpful by patients. Additionally, while more patients knew about the effects of the medications that they were taking, more caregivers emphasized the importance of medicine adherence. Psychosocial variables (e.g., family burden) demonstrated significant effects on both groups' mental health literacy. The government should invest more in supporting caregivers of people with mental disorders and monitor the implementation of mental health policies.
\end{abstract}

Keywords: mental health literacy; mainland China; patients; caregivers 


\section{Introduction}

Mental and behavioral disorders have become the leading causes of years lived with disability (YLDs) in mainland China, and the results of nationwide surveys show that lifetime prevalence of mental illness continues to increase $-1.4 \%$ in 1993, 13.2\% in 2002 and $16.6 \%$ in 2015 (Huang et al., 2019; Kessler \& Bedirhan, 2008; Yang et al., 2013; Zhang et al., 1998). Despite the government's efforts to establish high-quality mental health services to meet this increased demand for treatment and care, most of those with mental illnesses rely on family members for long-term care (Ma, 2012; National Health Commission of the People's Republic of China, 2015; Pan et al., 2016; Yu et al., 2018a; Zou et al., 2014). Family members are also often the ones who make decisions about treatment (e.g., admission and discharge), because in a Chinese context, people who are suffering from mental disorders are often considered incapable of making reasonable decisions due to their mental impairments (Chen \& Fan, 2010; Fan \& Wang, 2015). Responsibility for taking care of family members is a feature of China's mental health policies. For example, the Mental Health Law indicates that guardians should assist people with mental disorders to improve their social and independent living skills (National Health Commission of the People's Republic of China, 2013b). However, the central role of informal caregivers in treatment and caring has raised the question of whether they have sufficient knowledge to provide adequate support, and several studies have shown low levels of mental health literacy (MHL) in caregivers in China (e.g., Dixon et al., 2018; Li et al., 2017). 
MHL is defined as "knowledge and beliefs about mental disorders which aid their recognition, management or prevention” (Jorm et al., 1997; p.183). Previous interview-based studies have shown that Chinese caregivers prefer somatic or supernatural explanations for their relatives' mental illnesses (Li et al., 2017; Phillips et al., 2000). They also tended to view psychotherapy and counselling as ineffective and believed that mental illness could not be treated(Dixon et al., 2018; Li et al., 2017). Not surprisingly, a low level of MHL has also been observed in people with mental disorders, with evidence showing that most of them either do not know the causes of their illnesses or believe they are caused by morally inappropriate thinking (i.e., deviation from socially accepted behaviors). Only a few have heard of evidence-based treatments such as psychological therapies (Lai-Ming Hui et al., 2015; Li et al., 2017; Yu et al., 2018a). Lack of mental health knowledge and negative beliefs about mental disorders can prevent or delay professional help seeking. Indeed, lack of knowledge about their disorders has been described by patients as a key reason for refusing treatment (Ran et al., 2001). Caregivers' limited understanding of the causes of mental illness, incorrect interpretation of observed symptoms and distrust of treatments are also significant barriers to patients receiving timely and appropriate treatments (Askey et al., 2007; Dixon et al., 2018; McConnell, 2017).

Despite its importance, there has been limited research into patients’ and caregivers' MHL in mainland China, and most of the findings are based on one-to-one interviews or focus groups. To develop effective interventions to improve the quality of care and patients' knowledge and beliefs about their own illnesses (which have been shown to be important for 
early identification of mental illness, timely treatment, medicine adherence and reduced risk of relapse), a better understanding of both groups’ MHL is needed (Lau et al., 2018; Liu \& Zhang, 2019; Ran et al., 2016; Zou et al., 2014). To date, we have not been able to identify any published systematic or meta-analytic reviews of studies of caregivers' and patients' MHL in mainland China. Accordingly, we aimed to consolidate the available research by performing a systematic review of quantitative studies that examined mainland Chinese patients' and caregivers' knowledge and beliefs about mental illness, and factors predicting these.

\section{Method}

\section{Literature Search}

A systematic search was conducted of 5 English databases (Cochrane Library, Embase, PsycINFO, PubMed and Scopus) and 3 Chinese databases (CNKI, VIP and WanFang; see search terms in online supplementary material, Table A) by the first author. To identify additional papers, this was supplemented with a search of relevant journals (e.g., Medical Journal of Chinese People's Health), and reference lists of a relevant review (Hsiao \& Van Riper, 2010)and eligible studies. The initial search was deliberately kept broad to capture all potentially eligible papers.

\section{Eligibility Criteria}

Studies had to examine knowledge and/or beliefs about mental illness (e.g., causes, symptoms and treatment) and/or the correlates among people diagnosed with a mental illness and/or their caregivers in mainland China. In this review, caregivers were defined as informal 
caregivers (either primary or secondary) who provide care to a person with a mental disorder, such as family members or friends (Family caregiver alliance, 2014). Eligible studies also had to be journal articles published in English or Chinese between January 1997 (this is the date of publication of the definition of MHL; Jorm et al., 1997) and September 2019, and reported quantitative data (e.g., means, SDs) that could be converted into effect size $r$. In the case of 4 studies with overlapping samples (Feng et al., 2016; Li et al., 2018; Tang et al., 2015a; Tang et al., 2015b), only the studies providing more demographic information were included (Li et al., 2018; Tang et al., 2015a) to ensure data independence (Lipsey \& Wilson, 2001). In total, 48 studies with independent data were included in the current review (see Figure 1).

\section{Data Collection and Assessment of Study Reporting Quality}

Consistent with the PRISMA guidelines (Moher et al., 2009), study information (author, year, location where the research was conducted), methodological information (sample size, study design, measures, independent and dependent variables) and sample characteristics (age, gender, patients' mental illness, caregivers' relationships with patients) were extracted from eligible studies by the first author.

The quality of eligible studies was assessed for compliance with the Strengthening the Reporting of Observational Studies in Epidemiology checklist (STROBE; Vandenbroucke et al., 2007). Each of the 22 criteria was rated as met, met with some limitations, not met or not applicable, and the percentage of studies that met each criterion was calculated.

This article is protected by copyright. All rights reserved. 


\section{Statistical Analyses}

All data analyses were performed using the Comprehensive Meta-Analysis software (CMA Version 2.0; Biostat, 2005). In the case of 3 studies (Jiao et al., 2017; Li et al., 2016; Zhang et al., 2018) which examined MHL in both patients and caregivers, data for each sample group contributed to the analyses independently (Lipsey \& Wilson, 2001). To avoid bias, for 10 studies (Chen et al., 2008; Chen \& Tan, 2010; Chen et al., 2011; Ding \& Chen, 2012; Huang, 2013; Jin et al., 2006; Liu, 2009; Tan, 2005; Xing \& Kang, 2017; Xing et al., 2002) which investigated participants’ MHL before and after an intervention, only the data obtained before the intervention were utilized. Similarly, from 2 studies (Liu et al., 2005; Ran et al., 2003) which employed randomized controlled trails (RCTs) to test the effectiveness of psychoeducational interventions, only the datasets of the control groups (i.e., drug treatment only) were extracted and used. Thematic analysis approach was primarily applied to extract the theme that each survey item assesses. The identified themes were then classified into the following constructs according to the definition of MHL, namely recognition and knowledge of mental illness, causes, symptoms, negative outcomes of having a mental disorder, relapse, treatment and family involvement, beliefs about causes and treatment, and help-seeking intention. Each prevalence statistic (i.e., the response rate for each item) was then entered into CMA as an event rate (Abbey et al., 2015). The prevalence statistics were only pooled for studies that assessed the same theme. The included survey items can be found in the supplemental material (Table B). 
Pearson's correlation coefficient $(r)$ was the effect size metric utilized. Each $r$ value or an estimate that can be converted into an $r$ (i.e., odds ratio, $t$-value, $\mathrm{X}^{2}$ statistic), representing each relationship between an independent variable (e.g., age) and a construct relating to MHL (e.g., beliefs about antipsychotic medications), was extracted. For a study provided more than one $r$ for a relationship (i.e., for each gender group; Zhou et al., 2016), an average $r$ was calculated. Each $r$ value was then transformed into a Fisher’s Z. The Fisher's Z scores were subsequently weighted by the inverse of the variance and averaged. The weighted mean Fisher’s Z was back transformed to $r$ for interpretation (Lipsey \& Wilson, 2001). The transformation was computed automatically by the CMA software. It should be noted that $r$ values were only pooled for studies that used the same measures. Cohen's (1988) guidelines were employed to assess the magnitude of $r$, with .10, .30, and .50, representing small, medium, and large effect, respectively. 95\% confidence interval (CI) and $p$-value were also calculated to examine the statistical significance of each $r$ value (Lipsey \& Wilson, 2001). The heterogeneity of all pooled prevalence estimates and $r$ values was tested using $I^{2}$ index, with large $I^{2}$ statistics (i.e., $I^{2}>50 \%$ ) representing considerable heterogeneity (Lipsey \& Wilson, 2001). Subgroup analysis was also conducted to examine the effect of region (North versus South China) in the current findings, given people in different regions may have different understanding of mental illness due to the discrepancies in educational, economic and policy contexts (Ng et al., 2017; Sun et al., 2019). The random effect model was chosen for all analyses. 


\section{Results}

\section{Characteristics of Included Studies}

In all, 48 studies (6 in English and 42 in Chinese), involving a pooled sample of 11,895 participants (Mean age $=44$ ), were included in the review (Table 1). These included 36 crosssectional studies, 10 pre-post intervention studies and 2 RCTs. Eleven studies $(N=2,226$, Mean age $=41$, male-to-female ratio of 1.16 to 1$)$ focused only on patients, 34 studies $(N=8,241$, Mean age $=45$, male-to-female ratio of 1.04:1) recruited caregivers, and 3 studies $(N=1,428$, Mean age $=47$, male-to-female ratio of 1: 1.13) investigated MHL among both groups. Most of the studies originated from South China $(k=32, N=8,626)$.

\section{Study Evaluation}

According to the STROBE guidelines, although the majority of included studies provided detailed information on study design (item 4: 97.9\%) and setting (item 5: 93.8\%), other key components of the methodology, including participant recruitment procedure (item 6: 47.9\%; item 13c: 2.1\%), variables tested (item 7: 31.3\%), potential bias (item 9: 22.9\%), sample size justification (item 10: 0\%) and analysis procedure (item 11: 12.5\%; item 12b: 54.2\%;item 12e: 20.8\%; item 17: 20.8\%), were not well described. In addition, only a few studies explained missing data management (item 12c: 8.3\%; item 13a: 37.5\%; item 13b: 8.3\%). Importantly, whereas the findings were well presented (item 14a: 81.3\%; item 15: 100\%; item 18: 87.5\%), they were not always carefully interpreted (item 19: 10.4\%; item 20: 10.4\%; item 21: 45.8\%; see online supplementary material, Figure A).

This article is protected by copyright. All rights reserved. 


\section{Patients' knowledge and beliefs about mental illness}

Only $27.8 \%$ of the respondents recognized the symptoms of schizophrenia, and more than half considered stress (91.7\%), introversion (68.1\%), and abnormal body structure and function (61.7\%) as causes (Table 2). In terms of relapse, only a small percentage of respondents believed that mental illness was highly recurrent (6.6\%), and early treatment (7.1\%) and medicine adherence (4\%) could reduce the risk of relapse. For patients with schizophrenia or other severe mental disorders, more than $30 \%$ could identify the signs of relapse, and $90.5 \%$ declared that they knew how to deal with it.

Regarding available treatment for schizophrenia, 72.8\% of the respondents believed that medical treatment was the main treatment method, and most patients knew the names (66.4\%), appearance (81\%), and doses (79.3\%) of the antipsychotics that they were taking. Fewer than $45 \%$ knew about the therapeutic and side effects of the medications or how to deal with the side effects. Specifically, patients living in South China reported greater understanding of both therapeutic (South: 57.8\%, 95\%CI [48.7\%-66.4\%]; North: 24.5\%, 95\%CI [15.1\%-37.2\%]) and side effects (South: 46.2\%, 95\%CI [38.6\%-54\%]; North: 19.2\%, 95\%CI [10.9\%-31.5\%]). Although more than half of the patients admitted that one should not change the dose (64\%) or take medications intermittently (50\%), only 39.6\% recognized the importance of medicine adherence. More than half of the patients indicated that living with family and keeping contact with friends could reduce their symptoms, and their health status could be influenced by family members’ attitudes. On the contrary, keeping contact with mental health professionals (31.9\%) 
and attending rehabilitation training (13\%) were not highly rated as helpful. For patients with severe mental disorders, approximately $40 \%$ reported that they knew the names, doses and therapeutic effects of the medications that they were taking, but only $28.2 \%$ were aware of the side effects and fewer than 35\% realized the importance of medicine adherence.

\section{Correlates of patients' knowledge and beliefs about mental illness}

Length of illness, illness awareness and medication knowledge all demonstrated negative relationships with beliefs about antipsychotics, with small and medium to large effects, respectively (Table 3). Only two variables, beliefs about taking medications and medicine adherence, were examined and demonstrated significant and medium to large associations with patients' knowledge of their medications, with the former exhibited a positive effect, and the latter generated a negative relationship. Large effects of age and education level were found on their relationships with knowledge of mental illness in general, while small to medium and medium to large effects of residential area, marital status, education level and occupation were identified in the associations with knowledge of schizophrenia.

\section{Caregivers' knowledge and beliefs about mental illness}

Depression was recognized by $43.6 \%$ of caregivers, followed by schizophrenia (28.5\%) and anxiety disorders (18.1\%; Table 4). Approximately 65\% (46.6\%-77.5\%) declared that they could tell the names of the disorders that their ill relatives had, but only a few knew about the signs and symptoms (10.2\%-36.7\%) or how to identify them (11.7\%-13.2\%).Only 33.3\% knew the causes of severe mental illnesses, followed by schizophrenia (6.8\%), and depression and 
anxiety (3.5\%). Most caregivers attributed the onset of mental illness to negative life events (95.5\%), morally inappropriate thinking (68.9\%) or the co-occurrence of various factors (64.2\%), while positive attitudes, good interpersonal relationships and a healthy life style were considered to be effective buffers (96.1\%). For schizophrenia, the top five most frequently cited causes were psychological stress, introversion, work or financial problems, daily problems and weakness of character. Caregivers in North China were more likely to consider psychological stress (North: 95.6\%, 95\%CI [93\%-97.2\%]; South: 85\%, 95\%CI [77.4\%-90.3\%]) as the cause of schizophrenia, whereas caregivers in South China were inclined to view virus of infection (North: 6.7\%, 95\%CI [4.6\%-9.7\%]; South: 15\%, 95\%CI [10.7\%-20.6\%]), heredity (North: 21.9\%, 95\%CI [18.1\%26.3\%]; South: 46.6\%, 95\%CI [41.2\%-52.1\%]) and family environment (North: 50.7\%, 95\%CI [45.7\%-55.7\%]; South: 84.2\%, 95\%CI [76.5\%-89.7\%]) as possible causes. Similarly, for depression, the top five causes were work or financial problems, daily problems, recent traumatic events, weakness of character and death of someone else. Regarding relapse, $46 \%$ of caregivers declared that they knew the signs of relapse of severe mental illnesses, followed by schizophrenia (41.8\%), depression and anxiety (33.5\%), and any mental illness that the patient had (23\%), but only a few knew about how to prevent it (any mental illness: 20.2\%; schizophrenia: 9.1\%; severe mental illnesses: 6.5\%).

In terms of medical treatment, most caregivers believed that in addition to counseling, patients should also take medications regularly. However, although $41 \%$ knew the names of the medications that their ill relatives were taking, fewer knew about the duration of medical 
treatment (18.1\%), the therapeutic and side effects (2.9\%-35.8\%), and how to cope with the side effects (24.7\%). In the case of treating a specific disorder, only a few caregivers knew the names of the medications that the patients were taking for their schizophrenia (30\%) or severe mental illnesses of any type (25.8\%). A significant difference between North and South China on caregivers' familiarity with the medications for severe mental illnesses, including names (North: 42.8\%, 95\%CI [22.3\%-66.2\%]; South: 13.8\%, 95\%CI [5.6\%-30.3\%]) and side effects (North: 19.9\%, 95\%CI [15.7\%-24.8\%]; South: 43.3\%, 95\%CI [35.6\%-51.4\%]), was observed.

More than half of the respondents agreed with the importance of family involvement (e.g., keep the doctor updated) in the treatment for schizophrenia and any other severe mental disorders, but only a few knew how to provide care at home (schizophrenia: 17.5\%; severe mental illnesses: 18\%).Both formal (i.e., psychiatrists, mental health nurses and psychologists) and informal (i.e., family and friends) support were very highly rated as being helpful for both depression and schizophrenia. In relation to interventions, "becoming more physically active", "getting out and learning more”, "attending courses on relaxation”, “massage and having a rest”, and "receiving psychotherapy” were more often considered to be helpful for depression. In contrast, caregivers were more likely to view "cutting out alcohol" and "being admitted to a psychiatric ward" as helpful for schizophrenia. The top three most frequently cited activities for treating anxiety were "getting out and learning more", "attending courses on relaxation”, and “massage and have a rest". More than $70 \%$ of the respondents considered antipsychotics, antidepressants and anxiolytics to be helpful for schizophrenia, antidepressants and anxiolytics to 
be useful for depression, and antidepressants to be effective for anxiety. In terms of seeking professional help, a large proportion of caregivers (i.e., more than $80 \%$ ) agreed that one should seek professional help for mental illness and declared that they would accompany their ill relatives to the services.

\section{Correlates of caregivers' knowledge about mental illness}

Public stigma displayed the strongest negative association with caregivers' levels of mental health knowledge, while age, financial and daily life burden, caregivers’ physical health, and burden in family relationship and activity demonstrated medium to large or small to medium effects (Table 5). Having received psychoeducation and residential area were the only two variables which had positive relationships with the level of mental health knowledge. Burden in daily life, family relationship and family activity and caregivers' own physical health also demonstrated negative and small to medium associations with caregivers' levels of knowledge of recovery. A range of psychotic symptoms in caregivers (as measured by SCL-90-R) displayed small to medium negative effects on caregivers' levels of knowledge of schizophrenia. A positive and small to medium correlation was observed between caregivers' knowledge of mental illness and patient compliance with medication.

\section{Discussion}

This systematic review aimed to investigate patients' and caregivers' knowledge and beliefs about mental illness in mainland China. Our findings reveal that $43.6 \%$ of caregivers recognized depression, while only $28.5 \%$ and $18.1 \%$ identified schizophrenia and anxiety 
respectively. Both patients and caregivers tended to attribute the causes of mental illness to psychosocial factors (e.g., stress). Importantly, a discrepancy was noted in the two groups' knowledge of medications - while more patients knew about the names and effects of the medications, more caregivers emphasized the importance of medicine adherence. Non-standard interventions (e.g., "getting out and learning more”), mental health professionals and family members were all viewed as helpful for mental illness by caregivers. A range of modifiable (e.g., family burden) and non-modifiable (e.g., gender) variables were identified as significant correlates of patients' and/or caregivers' beliefs about medications and/or knowledge of mental illness, recovery and medications.

Noticeably, although caregivers' ability to recognize depression (43.6\%), schizophrenia (28.5\%) and anxiety (18.1\%) is much lower than primary healthcare workers (depression: 73.2\%; schizophrenia: 61.1\%; anxiety: 78.2\%), mental health professionals (depression: 68.4\%; schizophrenia: 66.1\%) and non-mental health professionals working at general hospitals (depression: 56.8\%; schizophrenia: 48.8\%; anxiety: 31.8\%) in mainland China, it is greater than medical students (depression: 38\%; schizophrenia: 12.4\%) and the general public (depression: 25.4\%; schizophrenia: 18.4\%; Li \& Reavley, 2019a; Li \& Reavley, 2019b). These findings may partially reflect caregivers' greater exposure to mental illness. Previous studies have observed that most persons with mental disorders rely on their families for long-term care in China - not only the basic care (e.g., financial support) but also medical administration, rehabilitation, health status monitoring (e.g., signs of relapse) and regular contacts with professionals (Hsiao \& Van 
Riper, 2010; Yu et al., 2018a; Zou et al., 2014). This review also found that most of the caregivers took an active role in cooperating with mental health professionals on follow-up care, and more caregivers than patients knew about the signs of relapse of schizophrenia and other severe mental disorders.

Regarding causes of mental illness, in contrast to Western populations, Chinese caregivers were less likely to attribute the onset of schizophrenia to biological factors (Angermeyer \& Matschinger, 1996), and more likely to consider psychosocial (e.g., stress) and personality (i.e., introversion) factors as important causes (i.e., more than $80 \%$ ). Patients showed a stronger tendency to attribute the development of schizophrenia to psychological stress (91.7\%) rather than other factors (e.g., heredity: 19.1\%). Future research could benefit from adopting interviews and/or focus groups to gain a deeper understanding of patients’ and caregivers’ own perspectives regarding the causes. Importantly, the current findings highlight both groups' lack of knowledge about causes of mental illness. Indeed, only a few caregivers (3.5\% - 33.3\%) in this review declared that they knew the causes of the illnesses that their ill relatives had (e.g., schizophrenia, depression). Given that one’s beliefs about causes can influence their future helpseeking behaviors and family members often play an important role in treatment decision making in China, mental health professionals should explain the possible causes of the illnesses to both patients and caregivers in the interviews, and consider psycho-educational approaches to improve both groups’ understanding of mental illness (Fan \& Wang, 2015; Hsiao \& Van Riper, 2010; Li et al., 2017; Yip, 2005). In addition, patients’ and caregivers’ beliefs in external factors 
may be attributable to their tendency to avoid stigma attached to people with mental disorders and their families (i.e., affiliate stigma; Mo et al., 2008; Pearson, 1993). Research conducted among Asian Americans and Indians has indeed identified that environmental or socio-economic explanations (e.g., stress, work and financial issues) of mental illness was associated with reduced social distance (Cheng, 2015; Kermode et al., 2009). However, future studies are needed to explore the relationship between causal attribution and stigma in mainland China.

Consistent with Western literature (Brodaty et al., 2003; Goodman et al., 1999), a favorable attitude towards ECT was found among patients and caregivers in China, but differences between groups in their understanding of medications were found. While more patients knew about the names and effects of medications that they were taking, a better understanding of medicine adherence was observed among caregivers. It could be that instead of giving adequate information about patients' illnesses (e.g., causes, symptoms and treatments), mental health professionals are inclined to place emphasis on the importance of medicine adherence when making suggestions to caregivers about the ongoing care at home. Indeed, previous studies in mainland China have consistently indicated that medicine management is the most frequently cited caregiving experience, and ensuring patients take medications as prescribed is the most common advice given by the professionals (Pearson, 1993; Yu et al., 2018b). Furthermore, we also found that patients' adherence to medications was positively related to their caregivers' knowledge of the illnesses but negatively associated with their own knowledge of medications. One possible explanation is that patients may become more worried 
about the adverse effects when they get to know more about the medications, while caregivers may be more worried about the negative outcomes of untreated illnesses and relapse. Indeed, the current review identified that $75.6 \%$ of patients were worried about the long-term effects of antidepressants, and $54.5 \%$ of caregivers knew about the negative outcomes caused by severe mental illnesses. To enhance patient adherence to medication, mental health professionals should therefore consider emphasizing more on positive consequences of medicine adherence when providing medicine information to patients, and continue providing individualized and adequate information about patients' illnesses to their caregivers.

Regarding beliefs about the helpfulness of pharmacological interventions, similar to health professionals working in China (i.e., mental health professional, non-mental health professionals working at general hospitals, and medical students; Li \& Reavley, 2019a), caregivers also tended to view antipsychotics as more helpful for schizophrenia, and antidepressants for depression and anxiety. In terms of non-pharmacological interventions, congruent with beliefs of professional groups (Li \& Reavley, 2019a), non-standard interventions (e.g., "getting out and learning more”) were rated highly (i.e., more than 90\%) for schizophrenia, depression and anxiety. The preference of non-specific activities may partially reflect caregivers' wishes for patients to return to society and re-establish "normal lives”. Indeed, previous research has identified that, in mainland China, caregivers usually define patients' recovery from mental illness as not only returning to health but also integrating into society (Ramsay, 2010). Hence, in addition to delivering effective treatments, mental health facilities should also help patients 
return to society such as providing rehabilitation services and occupational therapy.

Encouragingly, China's mental health policies, such as the 686 program and the Mental Health Law, have instructed local governments to establish community-based rehabilitation services (Ma, 2012; National Health Commission of the People's Republic of China, 2013b). However, our findings reveal that only a few caregivers knew about rehabilitation services (9.4\% - 25.2\%), and both patients and caregivers tended to view rehabilitation training as less helpful for schizophrenia (87\% - 85\%). These may reflect a gap between China's central policy and local implementation, thus the central government should develop effective strategies to support and monitor the implementation of mental health policies.

Among health professionals, psychiatrists were most often cited (87.7\% - 97\%) as helpful for schizophrenia, depression and anxiety by caregivers, followed by psychologists (schizophrenia: 96\%; depression: 93.1\%). These findings are consistent with Chinese health professionals' and public's beliefs that psychiatrists and psychologists are more helpful for schizophrenia and depression (Li \& Reavley, 2019a, 2019b). Noticeably, same with the professional group (Li \& Reavley, 2019a), caregivers are also inclined to consider family members as helpful for schizophrenia (92.5\%) and depression (87.6\%). However, potential family burden should be noted. Previous research has found that both objective (i.e., practical issues that arise due to patients' illness such as financial issues) and subjective (i.e., caregivers' emotional suffering due to the situation such as depression) family burn is higher in schizophrenia than in physical diseases (e.g., heart disease, diabetes; Magliano et al., 2005). Our 
findings also reveal that caregivers' psychological symptoms (as measured by SCL-90-R) and the increased family burden are associated with their decreased knowledge of patients' illnesses. It is possible that when the burden on caregivers increases, such as increased financial demands and own health problems, their attention will be distracted from caring for the patients.

Furthermore, the current review also provides some evidence that caregivers may be unprepared and struggle to provide ongoing care at home, for example, only $6.5 \%$ of caregivers knew about how to prevent relapse of severe mental illnesses. Therefore, in addition to providing treatment and support for patients, mental health professionals should also consider supportive interventions for caregivers such as family psychoeducation. Family psychoeducation focuses on benefiting both patients' and their family caregivers' well-being, and the content usually includes the information about patients' illnesses (e.g., treatment and medication) and coping strategies for dealing with unexpected situations (e.g., problem-solving skills; Lucksted et al., 2012). Cross-culturally, this intervention has been demonstrated as effective in reducing family burden, relapse and rehospitalization (Lucksted et al., 2012). Specifically, according to an RCT conducted in China (Ran et al., 2003), family psychoeducation can also improve family members' caring attitudes. This could be important for patients' recovery, given more than half of patients and caregivers in this review indicated that family members' negative attitudes could affect patients' conditions.

When delivering family psychoeducation to Chinese caregivers, strategies to assist in coping with stigma should also be included, taking into account the identified negative and 
strong relationship between perceived stigma and caregivers' levels of mental health knowledge. Fear of being stigmatized may prevent caregivers getting information about mental illness such as attending educational workshops (Li et al., 2017). It is also possible that the fear of stigma may stop caregivers attending family psychoeducation programs. Thus, policy makers and mental health professionals could consider promoting individual family psychoeducation. For example, Article 55 of the Mental Health Law indicates that community health professionals should regularly follow up people with severe mental illnesses who stay at home, and educate their caregivers about how to take care of the person (National Health Commission of the People's Republic of China, 2013b). This Article could be extended by including what practitioners can do to support caregivers during their visits, such as checking caregivers' physical and mental health status and asking about their recent concerns (e.g., financial issues).

Several limitations should be noted. First, because China's current mental health policies (e.g., the 686 program; Ma, 2012) focus primarily on severe mental illnesses (e.g., schizophrenia), most of the included studies examined MHL among people with these disorders and/or their caregivers, less attention has been given to other mental illnesses. Further investigation of MHL among persons with other mental disorders (e.g., eating disorders) and their caregivers is therefore needed. Second, several domains of MHL (e.g., recognition of mental disorders) were only examined in caregivers. Future empirical studies should consider investigating these among patients as well, in order to assist in the design and implementation of interventions for patients. Third, most of the included studies were conducted in South China ( $k$ 
= 32) and/or major cities. Although the difference between regions (i.e., North versus South China) on the current findings was explored, our analysis was restricted by the limited number of studies in North China $(k=16)$. Future research is therefore recommended to explore patients' and caregivers' MHL within different areas of China. Fourth, examination of different types of caregivers (e.g., patients' spouse, parents or children) as moderators was not possible as most included studies recruited family caregivers and did not provide separate data for each type. Finally, although patients' and caregivers' knowledge and beliefs about mental illness and treatment may change over time due to the progressive accumulation of their experiences, conclusions about this cannot be drawn from this review as no longitudinal studies were identified. Future longitudinal research using quantitative and/or qualitative methods is therefore suggested to explore the changes of patients’ and caregivers’ MHL in mainland China.

In conclusion, our findings advance the understanding of MHL among people with mental illness and their caregivers in mainland China - both groups prefer psychosocial explanations of mental illness and their knowledge and beliefs about medical treatment are inconsistent. The government should invest more resources in educating and supporting caregivers of people with mental illness.

\section{Data availability statement}

The data that support the findings of this study are available from the corresponding author upon reasonable request. 


\section{References}

References marked with an asterisk $\left(^{*}\right)$ indicate studies included in the systematic review.

Abbey, G., Thompson, S. B. N., Hickish, T., \& Heathcote, D. (2015). A meta-analysis of prevalence rates and moderating factors for cancer-related post-traumatic stress disorder. Psycho-Oncology, 24(4), 371-381. doi:doi:10.1002/pon.3654

Angermeyer, M. C., \& Matschinger, H. (1996). Relatives' beliefs about the causes of schizophrenia. Acta Psychiatrica Scandinavica, 93(3), 199-204. doi:10.1111/j.1600-0447.1996.tb10632.x

Askey, R., Gamble, C., \& Gray, R. (2007). Family work in first-onset psychosis: a literature review. Journal of Psychiatric and Mental Health Nursing, 14, 356-365. doi:10.1111/j.1365-2850.2007.01093.x

Biostat. (2005). Comprehensive Meta-Analysis (Version 2). Englewood, NJ: Biostat.

Brodaty, H., Berle, D., Hickie, I., \& Mason, C. (2003). Perceptions of Outcome from Electroconvulsive Therapy by Depressed Patients and Psychiatrists. Australian \& New Zealand Journal of Psychiatry, 37(2), 196-199. doi:10.1046/j.1440-1614.2003.01129.x

*Chen, H., Lin, Y., Wang, Y., \& Xu, H. (2019). Investigation on mental health education needs of senile patients with mental disorders in community. Health Education and Health Promotion, 14, 38-40. doi:10.16117/j.cnki.31-1974/r.201901012

*Chen, L., Zuo, H., \& Shen, H. (2008). Effect of family intervention on patients with schizophrenia. Medical Journal of Chinese People's Health, 20, 468-469. doi:10.3969/j.issn.1672-0369.2008.05.057

*Chen, M., Chen, Y., Wnag, J., \& Zhao, L. (2018a). Relationships between inpatients' knowledge of medications, beliefs about taking medications and medicine adherence Today Nurse, 25, 156-158.

*Chen, S., Wu, Q., Qi, C., Deng, H., Wang, X., He, H., . . Liu, T. (2017). Mental health literacy about schizophrenia and depression: A survey among Chinese caregivers of patients with mental disorder. $B M C$ Psychiatry, 17, 1-8. doi:10.1186/s12888-017-1245-y 
*Chen, S., Wu, Q., Wang, X., Qi, C., Long, J., He, H., . . Liu, T. (2018b). Knowledge of depression and GAD among caregivers of people with mental health issues. Chinese Mental Health Journal, 32, 923-925. doi:10.3969/j.issn.1000-6729.2018.11.007

Chen, X., \& Fan, R. (2010). The family and harmonious medical decision making: cherishing an appropriate Confucian moral balance. J Med Philos, 35(5), 573-586. doi:10.1093/jmp/jhq046

*Chen, X., \& Liu, X. (2006). Investigation on knowledge of mental illness among family caregivers of people with mental illness. Acta Medicinae Sinica, 19, 568-569. doi:10.3969/j.issn.1008-2409.2006.03.115

*Chen, Y., \& Tan, L. (2010). Mental health knowledge of family caregivers of outpatients and relevant intervention strategies. Today Nurse, 2010, 76-78.

*Chen, Z., Gao, Z., Wu, M., Li, H., Luo, M., \& Lin, W. (2011). Analysis on the effects of health education in the community based for schizophrenic patients in Shantou City of Guangdong Province. Chinese Journal of Health Education, 27, 671-674.

Cheng, Z. H. (2015). Asian Americans and European Americans’ stigma levels in response to biological and social explanations of depression. Social Psychiatry and Psychiatric Epidemiology, 50(5), 767-776. doi:10.1007/s00127-014-0999-5

Cohen, J. (1988). Statistical power analysis for the behavioral sciences (2nd ed.). Hillsdale, NJ: Erlbaum.

*Ding, K., \& Chen, Q. (2012). Effects of a community based intervention and education needs among family caregivers of patients with schizophrenia. Zhejiang Preventive Medicine, 24, 67-69.

Dixon, J., Lei, J., Huang, W., Sin, J., \& Smith, G. (2018). The Views of Mental Health Manager Towards the Use of a Family Work Model for Psychosis in Guangzhou, China. Community Ment Health J, 54(7), 1057-1063. doi:10.1007/s10597-018-0247-7

Family caregiver alliance. (2014). Definitions. Retrieved from https://www.caregiver.org/definitions-0

Fan, R., \& Wang, M. (2015). Taking the Role of the Family Seriously in Treating Chinese Psychiatric Patients: A Confucian Familist Review of China's First Mental Health Act. Journal of Medicine and Philosophy, 40(4), 387-399. doi:10.1093/jmp/jhv014 
Feng, H., Hu, X.-F., Xu, Z.-Y., \& Zhang, J.-M. (2016). Survey of demands of schizophrenic caregivers for knoweldge of disease and health education. Nursing Practice and Research, 13(23), 72-74.

*Gao, X., Li, L., \& Chen, J. (2004). The demand and attitude toward knowledge of mental health in family member of psychopathic patients. Chinese Journal of Behavioral Medical Science, 13, 550-551. doi:10.3760/cma.j.issn.1674-6554.2004.05.040

Goodman, J. A., Krahn, L. E., Smith, G. E., Rummans, T. A., \& Pileggi, T. S. (1999). Patient satisfaction with electroconvulsive therapy. Mayo Clinic Proceedings, 74, 967-971.

Hsiao, C. Y., \& Van Riper, M. (2010). Research on caregiving in Chinese families living with mental illness: a critical review. J Fam Nurs, 16(1), 68-100. doi:10.1177/1074840709358405

*Huang, H. (2013). Evaluation on hte health education for the relatives of patients with severe mental disease. Modern Preventive Medicine, 40, 3237-3238+3245.

Huang, Y., Wang, Y., Wang, H., Liu, Z., Yu, X., Yan, J., . . W Wu, Y. (2019). Prevalence of mental disorders in China: a cross-sectional epidemiological study. The Lancet Psychiatry, 6(3), 211-224. doi:https://doi.org/10.1016/S2215-0366(18)30511-X

*Jiao, Y., Wang, L., Zhou, Y., Bai, X., \& Li, G. (2017). Mental health knowledge among patients with schizophrenia in the stable period and their caregivers. Guangdong Medical Journal, 38, 2680-2683. doi:10.3969/j.issn.1001-9448.2017.17.027

*Jin, D., Zhang, X., Wang, M., \& Duan, W. (2006). Effect evaluation of home education of community schizophrenia patient. Journal of Nursing (China), 13, 63-65.

Jorm, A. F., Korten, A. E., Jacomb, P. A., Christensen, H., Rodgers, B., \& Pollitt, P. (1997). "Mental health literacy": A survey of the public's ability to recognise mental disorders and their beliefs about the effectiveness of treatment. Medical Journal of Australia, 166, 182-186.

Kermode, M., Bowen, K., Arole, S., Pathare, S., \& Jorm, A. F. (2009). Attitudes to people with mental disorders: a mental health literacy survey in a rural area of Maharashtra, India. Social Psychiatry and Psychiatric Epidemiology, 44(12), 1087-1096. doi:10.1007/s00127-009-0031-7 
Kessler, R. C., \& Bedirhan, U. T. (2008). The WHO world mental health surveys: global perspectives on the epidemiology of mental disorders. New York: Cambridge University Press, 2008.

Lai-Ming Hui, C., Wing-Yan Poon, V., Shuk-Kuen Kwok, V., Chang, W.-C., Kit-Wa Chan, S., Ho-Ming Lee, E., \& Yu-Hai Chen, E. (2015). Prevalence and predictors of medication non-adherence among Chinese patients with first-episode psychosis. Psychiatry Research, 228(3), 680-687. doi:https://doi.org/10.1016/j.psychres.2015.04.047

Lau, K. C.-K., Lee, E. H.-M., Hui, C. L.-M., Chang, W.-C., Chan, S. K.-W., \& Chen, E. Y.-H. (2018). Demographic correlates of medication knowledge in Hong Kong early psychosis patients. Early Interv Psychiatry, 12(1), 107-112. doi:10.1111/eip.12351

*Li, C., \& Sun, H. (2016). Stigma and related factors of psychiatric patients' family members. China Journal of Health Psychology, 24, 343-347. doi:10.13342/j.cnki.cjhp2016.03.006

*Li, D., \& Zhao, L. (2018). Mental health knoweldge among caregviers of people with severe mental illness in Guyuan City. Ningxia Medical Journal, 40, 86-88. doi:10.13621/j.1001-5949.2018.01.0086

*Li, H., Xu, C.-Y., \& Hu, X.-F. (2018). Education needs of caregivers of patients with schizophrenia. Today Nurse, 25, 35-37.

*Li, L., Li, H., Huang, L., \& Mei, F. (2006). A survey of knowledge of mental health among the relatives of psychiatric patients. Journal of Nursing (China), 13, 19-21. doi:10.3969/j.issn.1008-9969.2006.06.008

Li, W., \& Reavley, N. J. (2019a). The mental health literacy of healthcare workers in mainland China: A systematic review. Manuscript submitted for publication.

Li, W., \& Reavley, N. J. (2019b). Recognition and beliefs about treatment for mental disorders in mainland China: A systematic review and meta-analysis. Manuscript submitted for publication.

Li, W., Zhang, L., Luo, X., Liu, B., Liu, Z., Lin, F., . . Naeem, F. (2017). A qualitative study to explore views of patients', carers' and mental health professionals' to inform cultural adaptation of CBT for psychosis (CBTp) in China. BMC Psychiatry, 17(1), 131. doi:10.1186/s12888-017-1290-6 
*Li, X. (2007). Needs of the families of discharged psychiatric patients for health education. Journal of Nursing (China), 14, 28-29.

*Li, Y., An, F. R., Zhu, H., Chiu, H. F., Ungvari, G. S., C, H. N., . . Xiang, Y. T. (2016). Knowledge and Attitudes of Patients and Their Relatives Toward Electroconvulsive Therapy in China. Perspect Psychiatr Care, 52, 248-253. doi:10.1111/ppc.12124

Lipsey, M. W., \& Wilson, D. B. (2001). Practical meta-analysis Thousand Oaks, Calif.: Sage Publications.

*Liu, L., Xu, K., Yue, S., Liu, W., \& Fu, F. (2005). The follow-up study on the rehabilitation effect of cognition insight therapy in patients with schizophrenia. Journal of Nursing Administration, 5, 15-18. doi:10.3969/j.issn.1671-315X.2005.01.006

*Liu, M., Fu, X., \& Xu, Y. (2004). Investigation on mental health knowledge needs of family caregivers of inpatients with mental illness. Chinese Journal of General Practice, 3, 44-45.

Liu, N., \& Zhang, J. (2019). Experiences of caregivers of family member with schizophrenia in China: A qualitative study. Perspectives in Psychiatric Care, O(0), 1-12. doi:10.1111/ppc.12412

*Liu, Y.-L. (2009). Effect of health education on schizophrenia patients recovery. Journal of Heze Medical College, 21, 49-51.

*Lou, L. (2013). Survey and countermeasures of health education demand of fmaily members of patients with severe mental illness. Chinese Nursing Research, 27, 2977-2979.

*Lu, Y., Arthur, D., Hu, L., Cheng, G., An, F., \& Li, Z. (2016). Beliefs about antidepressant medication and associated adherence among older Chinese patients with major depression: A cross-sectional survey. Int $J$ Ment Health Nurs, 25, 71-79. doi:10.1111/inm.12181

Lucksted, A., McFarlane, W., Downing, D., \& Dixon, L. (2012). Recent Developments in Family Psychoeducation as an Evidence-Based Practice. Journal of Marital and Family Therapy, 38(1), 101-121. doi:10.1111/j.1752-0606.2011.00256.x

*Luo, W., \& Deng, M. (2002). An investigation of the health education needs of family members of psychiatric patients. Chinese Journal of Clinical Psychology, 10, 50-51. 
Ma, H. (2012). Integration of hospital and community services — the '686 Project' —is a crucial component in the reform of China's mental health services. Shanghai Archives of Psychiatry, 24, 172-174.

doi:10.3969/j.issn.1002-0829.2012.03.007

Magliano, L., Fiorillo, A., De Rosa, C., Malangone, C., \& Maj, M. (2005). Family burden in long-term diseases: a comparative study in schizophrenia vs. physical disorders. Social Science \& Medicine, 61(2), 313-322. doi:10.1016/j.socscimed.2004.11.064

McConnell, W. R. (2017). Cultural Guides, Cultural Critics: Distrust of Doctors and Social Support during Mental Health Treatment. Journal of Health and Social Behavior, 58(4), 503-519. doi:10.1177/0022146517736291

Mo, F. Y. M., Chung, W. S., Wong, S. W., Chun, D. Y. Y., Wong, K. S., \& Chan, S. S. M. (2008). Experience of caregiving in caregivers of patients with first-episode psychosis. Hong Kong Journal of Psychiatry, 18, 101-106.

Moher, D., Liberati, A., Tetzlaff, J., \& Altman, D. G. (2009). Preferred reporting items for systematic reviews and meta-analyses: the PRISMA statement. Annals of Internal Medicine, 151, 264-269.

National Health Commission of the People's Republic of China. (2013a). Management of Severe Mental Disorders. Beijing Retrieved from http://www.gov.cn/jrzg/2013-09/02/content_2479713.htm.

National Health Commission of the People's Republic of China. (2013b). The Mental Health Law of the People's Republic of China. Beijing Retrieved from http://www.gov.cn/flfg/2012-10/26/content_2253975.htm.

National Health Commission of the People's Republic of China. (2015). National Mental Health Work Plan of the People's Republic of China: 2015-2020. Beijing Retrieved from http://www.gov.cn/zhengce/content/2015$\underline{\text { 06/18/content_9860.htm. }}$

Ng, R. M. K., Lee, C. K., Liu, J., Luo, J., Zu, S., Mi, S., \& Li, Z. (2017). Psychotherapy Services in China: Current Provisions and Future Development. Journal of Contemporary Psychotherapy(2), 87. doi:10.1007/s10879016-9345-4 
Pan, J. Y., Ng, Y. P., \& Young, K. D. (2016). The impact of caregivers on the effectiveness of an early community mental health detection and intervention programme in Hong Kong. Early Interv Psychiatry, 10(6), 494502. doi:10.1111/eip.12200

Pearson, V. (1993). Families in China: an undervalued resource for mental health? Journal of Family Therapy, 15(2), 163-185. doi:10.1111/j.1467-6427.1993.00752.x

Phillips, M. R., Li, Y., Stroup, T. S., \& Xin, L. (2000). Causes of schizophrenia reported by patients' family members in China. British Journal of Psychiatry, 177(1), 20-25. doi:10.1192/bjp.177.1.20

*Ping, H., Shen, Q., \& Chen, L. (2012). Cognition and need of maintenance treatment for patients with schizophrenia in remission stage. Journal of Nursing (China), 19, 26-28.

*Qu, Z., Liu, T., \& Wei, D. (2014). Coping styles and health education needs of caregivers for abnormal behaviors of schizophrenia patients. Practical Clincial medicine, 15, 108-113.

Ramsay, G. (2010). Mainland Chinese family caregiver narratives in mental illness: Disruption and continuity. Asian Studies Review, 34(1), 83-103. doi:10.1080/10357820903568219

Ran, M.-S., Chui, C. H. K., Wong, I. Y.-L., Mao, W.-J., Lin, F.-R., Liu, B., \& Chan, C. L.-W. (2016). Family caregivers and outcome of people with schizophrenia in rural China: 14-year follow-up study. Social Psychiatry and Psychiatric Epidemiology, 51(4), 513-520. doi:10.1007/s00127-015-1169-0

Ran, M., Xiang, M., Huang, M., \& Shan, Y. (2001). Natural course of schizophrenia: 2-year follow-up study in a rural Chinese community. British Journal of Psychiatry, 178(2), 154-158. doi:10.1192/bjp.178.2.154

*Ran, M. S., Xiang, M. Z., Chan, C. L., Leff, J., Simpson, P., Huang, M. S., . . Li, S. G. (2003). Effectiveness of psychoeducational intervention for rural Chinese families experiencing schizophrenia--a randomised controlled trial. Soc Psychiatry Psychiatr Epidemiol, 38, 69-75. doi:10.1007/s00127-003-0601-z

Sun, X., Ge, J., Meng, H., Chen, Z., \& Liu, D. (2019). The Influence of Social Support and Care Burden on Depression among Caregivers of Patients with Severe Mental Illness in Rural Areas of Sichuan, China. International Journal of Environmental Research and Public Health, 16(11), 1961. 
*Tan, J. (2005). Effect of health education on medicine adherence of patients with schizophrenia. Journal of Youjiang Medical College for Nationalities, 27, 723-724.

*Tang, H., Huang, B., Niu, D., \& Chu, J. (2015a). Survey of disease knowledge and family burden of family caregivers of community schizophrenic patients. Medical Journal of Chinese People's Health, 27, 84$85+112$.

Tang, H. X., Huang, B., Niu, D. D., Zang, J., \& Chu, J. (2015b). Effect of the family guidance intervention on the patients with schizophrenia in the stable period and their family members. Shanghai Medical \& Pharmaceutical Journal, 36, 49-52.

*Tang, J., Lu, X., Chen, L., \& Liu, Y. (2016). Survey and influencing factor analysis of the awareness and utilization of socil resources among schizophrenia patients and their family members in Beijing urban communities. Chinese General Practice, 19, 2459-2463. doi:10.3969/j.issn.1007-9572.2016.20.021

Vandenbroucke, J. P., von Elm, E., Altman, D. G., Gøtzsche, P. C., Mulrow, C. D., Pocock, S. J., . . Egger, M. (2007). Strengthening the Reporting of Observational Studies in Epidemiology (STROBE): Explanation and elaboration. PLOS ONE, 4, 1628-1654. doi:10.1371/journal.pmed.0040297

*Wang, J., Tang, L., Zhang, N., Wen, Y., Zheng, W., Wu, S., . . Ma, X. (2012). Cognition and need for community mental health services in patients with severe mental disorders. Chinese General Practice, 15, 4089-4091.

*Wang, Y., Zhai, L., Li, K., Li, W., Zhao, C., \& Zeng, L. (2014). Relationship between mental health and schizophrenia knowledge among relatives of first-episode schizophrenia patients. China Medical Herald, $11,88-90+95$.

*Wang, Z., \& Yin, D. (2016). Survey of related knowledge of family members of mental disorder patients. Chinese Nursing Research, 30, 190-191. doi:10.3969/j.issn.1009-6493.2016.02.022

*Wen, Y., Zhao, G. D., \& Qin, Q. L. (2008). Knowledge of mental illness and health education needs among family caregivers of outpatients in a psychiatric hospital. Intenal Medicine of China, 3, 454-455. doi:10.3969/j.issn.1673-7768.2008.03.072 
*Xing, C., \& Kang, P. (2017). Effects of family members' illness-related knowledge education on their family support of patients with depression and anxiety disorders. Medical Journal of Chinese People's Health, 29, 57-60. doi:10.3969/j.issn.1672-0369.2017.11.025

*Xing, S., Xi, H., \& Xu, J. (2002). Effect of health eduction on improving medicine adherence among caregivers of patients with schizophrenia. Chinese Journal of Clinical Rehabilitation, 6, 1630-1631.

Yang, G., Wang, Y., Zeng, Y., Gao, G. F., Liang, X., Zhou, M., . . Murray, C. J. L. (2013). Rapid health transition in China, 1990-2010: findings from the Global Burden of Disease Study 2010. The Lancet, 381(9882), 1987-2015. doi:https://doi.org/10.1016/S0140-6736(13)61097-1

*Yang, Q., Xiu, Y., Ke, Z., \& Liao, Y. (2018). Effect of knowledge and behavioral level of caregivers on medication compliance in patients with severe mental disorders. Journal of Guangdong Medical University, 36, 581584.

Yip, K. S. (2005). Family caregiving of clients with mental illness in the People’s Republic of China. International Journal of Psychosocial Rehabilitation, 9, 19-30.

Yu, S., Kowitt, S. D., Fisher, E. B., \& Li, G. (2018a). Mental Health in China: Stigma, Family Obligations, and the Potential of Peer Support. Community Ment Health J, 54(6), 757-764. doi:10.1007/s10597-017-0182-z

*Yu, X., Sun, Z., \& Fu, Y. (2006). A study of coping style, mental health status and needs of health education in the relatives of schizophrenic patients. Shandong Archive of Psychiatric, 19, 17-20.

Yu, Y., Tang, B.-w., Liu, Z.-w., Chen, Y.-m., Zhang, X.-y., \& Xiao, S. (2018b). Who cares for the schizophrenia individuals in rural China — A profile of primary family caregivers. Comprehensive Psychiatry, 84, 47-53. doi:https://doi.org/10.1016/j.comppsych.2018.04.002

*Zhang, M., Guo, M., \& He, J. (2011). An investigation and analysis of hte treatment status of neurosis patients. Lab Medicine and Clinic, 8, 828-829. doi:10.3969/j.issn.1672-9455.2011.07.027

*Zhang, Q., Huang, S., Jiang, L., Wu, C., \& Song, M. (2014). A cross sectional survey on hte mental health knowledge and the perceived stigma among family members of patients with schizophrenia. China Medical Herald, 11, 103-106. 
*Zhang, Q. E., Zhou, F. C., Zhang, L., Ng, C. H., Ungvari, G. S., Wang, G., \& Xiang, Y. T. (2018). Knowledge and attitudes of older psychiatric patients and their caregivers towards electroconvulsive therapy. Psychogeriatrics, 18, 343-350. doi:10.1111/psyg.12326

Zhang, W., Shen, Y., Li, S., Chen, C. Y., \& Huang, Y. (1998). Epidemiological investigation on mental disorders in seven areas of China. Chinese Journal of Psychiatry, 2, 69-71.

*Zhang, W., Zhang, G., Shen, W., Liu, H., Zhao, J., \& Zhou, Q. (2010). KAP about psychosis among family members of psychopathic patients in Xuhui District. Chinese Primary Health Care, 24, 22-24.

*Zhao, B., Lei, X., Yang, M., Yang, F., \& Wei, L. (2013). Influence of the psychosocial factors on the family burden of psychotic patients in community. Hainan Medical Journal, 24, 1148-1151. doi:10.3969/j.issn.1003-6350.2013.08.0487

*Zhao, G., \& Liang, X. (2005). Knowledge of mental illness and information needs among family caregivers of psychiatric patients. Modern Clinical Nursing, 4, 51-53. doi:10.3969/j.issn.1671-8283.2005.06.023

*Zhou, J., Xiang, Y. T., Li, Q., Zhu, X., Li, W., Ungvari, G. S., . . W Wang, X. (2016). Gender differences in attitudes towards antipsychotic medications in patients with schizophrenia. Psychiatry Res, 245, 276-281. doi:10.1016/j.psychres.2016.08.041

*Zhu, C. (2009). The demand of psychotic srelation for telephone visit to guide patient's healing. Modern Hospital, 9, 154-155.

*Zhu, W., Cui, Y., Han, L., \& Huang, Q. (2018). Investigation on knoweldge of mental health among family caregivers of persons with severe mental illness in Shantou. Journal of Shantou University Medical College, $31,121-124$.

Zou, H., Li, Z., Arthur, D., \& Wang, H. (2014). Self-management in Chinese people with schizophrenia and their caregivers: a qualitative study on facilitators and barriers. Int J Ment Health Nurs, 23(4), 355-363. doi:10.1111/inm.12055 
Table 1

Description of 48 Studies Included in the Review

\begin{tabular}{|c|c|c|c|c|c|c|c|c|c|c|}
\hline \multirow{2}{*}{ Study } & \multirow[b]{2}{*}{$\begin{array}{l}\text { Region } \\
\text { (Province) }\end{array}$} & \multirow[b]{2}{*}{$N$} & \multirow[b]{2}{*}{ Mean age } & \multirow[b]{2}{*}{ Gender } & \multirow[b]{2}{*}{$\begin{array}{l}\text { Patient's } \\
\text { illness }\end{array}$} & \multirow[b]{2}{*}{ Sample type } & \multicolumn{2}{|c|}{ Prevalence } & \multicolumn{2}{|c|}{ Correlation } \\
\hline & & & & & & & Theme & Measure & $\begin{array}{l}\text { Dependent } \\
\text { variable }\end{array}$ & Measure \\
\hline $\begin{array}{l}\text { Chen et al. } \\
\text { (2008) }\end{array}$ & $\begin{array}{l}\text { South } \\
\text { (Hubei) }\end{array}$ & 200 & 41 & $\begin{array}{l}\text { male }(58 \%) ; \\
\text { female }(42 \%)\end{array}$ & schizophrenia & $\begin{array}{l}\text { caregiver } \\
\text { (family) }\end{array}$ & $\begin{array}{l}\text { knowledge of treatment, } \\
\text { causes, mental illness }\end{array}$ & self-designed & $\mathrm{n} / \mathrm{a}$ & $\mathrm{n} / \mathrm{a}$ \\
\hline $\begin{array}{l}\text { Chen et al. } \\
\text { (2011) }\end{array}$ & $\begin{array}{l}\text { South } \\
\text { (Guangdong) }\end{array}$ & 198 & 38.9 & $\begin{array}{l}\text { male }(64.1 \%) ; \\
\text { female } \\
(35.9 \%)\end{array}$ & schizophrenia & patient & $\begin{array}{l}\text { knowledge of treatment, } \\
\text { relapse, symptoms, causes }\end{array}$ & self-designed & $\mathrm{n} / \mathrm{a}$ & $\mathrm{n} / \mathrm{a}$ \\
\hline $\begin{array}{l}\text { Chen et al. } \\
\text { (2017) }\end{array}$ & $\begin{array}{l}\text { South } \\
\text { (Hunan) }\end{array}$ & 402 & 41.1 & $\begin{array}{l}\text { male }(41.5 \%) \text {; } \\
\text { female } \\
(58.5 \%)\end{array}$ & $\begin{array}{l}\text { any mental } \\
\text { illness }\end{array}$ & $\begin{array}{l}\text { caregiver } \\
\text { (family or } \\
\text { friend) }\end{array}$ & $\begin{array}{l}\text { recognition; beliefs about } \\
\text { causes, treatment }\end{array}$ & $\begin{array}{l}\text { Jorm’s } \\
\text { vignettes }\end{array}$ & $\mathrm{n} / \mathrm{a}$ & $\mathrm{n} / \mathrm{a}$ \\
\hline $\begin{array}{l}\text { Chen et al. } \\
\text { (2018b) }\end{array}$ & $\begin{array}{l}\text { South } \\
\text { (Hunan) }\end{array}$ & 204 & $\mathrm{n} / \mathrm{a}$ & $\mathrm{n} / \mathrm{a}$ & $\begin{array}{l}\text { any mental } \\
\text { illness }\end{array}$ & $\begin{array}{l}\text { caregiver } \\
\text { (family) }\end{array}$ & $\begin{array}{l}\text { beliefs about treatment; } \\
\text { recognition }\end{array}$ & $\begin{array}{l}\text { Jorm’s } \\
\text { vignette }\end{array}$ & $\mathrm{n} / \mathrm{a}$ & $\mathrm{n} / \mathrm{a}$ \\
\hline $\begin{array}{l}\text { Chen et al. } \\
\text { (2018a) }\end{array}$ & $\begin{array}{l}\text { South } \\
\text { (Hunan) }\end{array}$ & 182 & 26.6 & male (100\%) & $\begin{array}{l}\text { severe mental } \\
\text { illnesses }\end{array}$ & patient & knowledge of treatment & self-designed & $\begin{array}{l}\text { knowledge of the } \\
\text { medication that } \\
\text { he/she is taking }\end{array}$ & $\begin{array}{l}\text { self- } \\
\text { designed }\end{array}$ \\
\hline $\begin{array}{l}\text { Chen et al. } \\
\text { (2019) }\end{array}$ & $\begin{array}{l}\text { South } \\
\text { (Shanghai) }\end{array}$ & 400 & $\mathrm{n} / \mathrm{a}$ & $\begin{array}{l}\text { male }(48 \%) ; \\
\text { female }(52 \%)\end{array}$ & $\begin{array}{l}\text { severe mental } \\
\text { illnesses }\end{array}$ & patient & $\begin{array}{l}\text { knowledge of treatment, } \\
\text { family involvement, } \\
\text { relapse }\end{array}$ & self-designed & $\begin{array}{l}\text { knowledge of } \\
\text { mental illness }\end{array}$ & $\begin{array}{l}\text { self- } \\
\text { designed }\end{array}$ \\
\hline $\begin{array}{l}\text { Chen and Liu } \\
\text { (2006) }\end{array}$ & $\begin{array}{l}\text { South } \\
\text { (Guangdong) }\end{array}$ & 280 & $\mathrm{n} / \mathrm{a}$ & $\mathrm{n} / \mathrm{a}$ & $\begin{array}{l}\text { any mental } \\
\text { illness }\end{array}$ & $\begin{array}{l}\text { caregiver } \\
\text { (family) }\end{array}$ & $\begin{array}{l}\text { knowledge of treatment, } \\
\text { family involvement, } \\
\text { relapse, causes, symptoms }\end{array}$ & self-designed & $\mathrm{n} / \mathrm{a}$ & $\mathrm{n} / \mathrm{a}$ \\
\hline $\begin{array}{l}\text { Chen and Tan } \\
\text { (2010) }\end{array}$ & $\begin{array}{l}\text { South } \\
\text { (Hunan) }\end{array}$ & 804 & 40.2 & $\begin{array}{l}\text { male }(51.5 \%) ; \\
\text { female } \\
(48.5 \%)\end{array}$ & $\begin{array}{l}\text { any mental } \\
\text { illness }\end{array}$ & $\begin{array}{l}\text { caregiver } \\
\text { (family) }\end{array}$ & $\begin{array}{l}\text { knowledge of treatment, } \\
\text { symptoms }\end{array}$ & self-designed & $\mathrm{n} / \mathrm{a}$ & $\mathrm{n} / \mathrm{a}$ \\
\hline $\begin{array}{l}\text { Ding and Chen } \\
\text { (2012) }\end{array}$ & $\begin{array}{l}\text { South } \\
\text { (Zhejiang) }\end{array}$ & 458 & 54.7 & $\begin{array}{l}\text { male }(40.2 \%) \text {; } \\
\text { female } \\
(59.8 \%)\end{array}$ & schizophrenia & $\begin{array}{l}\text { caregiver } \\
\text { (family) }\end{array}$ & $\begin{array}{l}\text { knowledge of mental } \\
\text { illness, treatment, family } \\
\text { involvement, relapse, } \\
\text { symptoms, causes }\end{array}$ & self-designed & $\mathrm{n} / \mathrm{a}$ & $\mathrm{n} / \mathrm{a}$ \\
\hline Gao et al. & South & 79 & 42.2 & male (54.4\%); & any mental & caregiver & beliefs about treatment; & self-designed & $\mathrm{n} / \mathrm{a}$ & $\mathrm{n} / \mathrm{a}$ \\
\hline
\end{tabular}




\begin{tabular}{llll} 
(2004) (Hunan) & female \\
$(45.6 \%)$ & illness & (family) & $\begin{array}{l}\text { help-seeking intention; } \\
\text { knowledge of mental } \\
\text { illness }\end{array}$ \\
\hline
\end{tabular}

This article is protected by copyright. All rights reserved. 
Table 1

Continued

\begin{tabular}{|c|c|c|c|c|c|c|c|c|c|c|}
\hline \multirow{2}{*}{ Study } & \multirow[b]{2}{*}{$\begin{array}{l}\text { Region } \\
\text { (Province) }\end{array}$} & \multirow[b]{2}{*}{$N$} & \multirow[b]{2}{*}{ Mean age } & \multirow[b]{2}{*}{ Gender } & \multirow[b]{2}{*}{$\begin{array}{l}\text { Patient's } \\
\text { illness }\end{array}$} & \multirow[b]{2}{*}{$\begin{array}{l}\text { Sample } \\
\text { type }\end{array}$} & \multicolumn{2}{|c|}{ Prevalence } & \multicolumn{2}{|c|}{ Correlation } \\
\hline & & & & & & & Theme & Measure & $\begin{array}{l}\text { Dependent } \\
\text { variable }\end{array}$ & Measure \\
\hline Huang (2013) & $\begin{array}{l}\text { South } \\
\text { (Sichuan) }\end{array}$ & 150 & 37.2 & $\begin{array}{l}\text { male }(40.7 \%) ; \\
\text { female }(59.3 \%)\end{array}$ & $\begin{array}{l}\text { severe mental } \\
\text { illnesses }\end{array}$ & $\begin{array}{l}\text { caregiver } \\
\text { (family) }\end{array}$ & $\begin{array}{l}\text { knowledge of } \\
\text { mental illness, } \\
\text { treatment, family } \\
\text { involvement, } \\
\text { relapse, causes, } \\
\text { symptoms }\end{array}$ & self-designed & $\mathrm{n} / \mathrm{a}$ & $\mathrm{n} / \mathrm{a}$ \\
\hline $\begin{array}{l}\text { Jiao et al. } \\
\text { (2017) }\end{array}$ & $\begin{array}{l}\text { North } \\
\text { (Inner } \\
\text { Mongolia) }\end{array}$ & $\begin{array}{l}\text { patient: } \\
\text { 386; } \\
\text { caregiver: } \\
386\end{array}$ & $\begin{array}{l}\text { patient: } \\
39.8 \text {; } \\
\text { caregiver: } \\
49.2\end{array}$ & $\begin{array}{l}\text { patient: male } \\
\text { (57.3\%); female } \\
\text { (42.7\%) } \\
\text { caregiver: male } \\
(37.3 \%) \text {; female } \\
(62.7 \%)\end{array}$ & schizophrenia & $\begin{array}{l}\text { patient \& } \\
\text { caregiver } \\
(\mathrm{n} / \mathrm{a})\end{array}$ & $\begin{array}{l}\text { knowledge of } \\
\text { treatment, family } \\
\text { involvement; beliefs } \\
\text { about treatment, } \\
\text { causes }\end{array}$ & $\begin{array}{l}\text { Knowledge- } \\
\text { Attitude-Practice } \\
\text { Awareness } \\
\text { Questionnaire }\end{array}$ & $\begin{array}{l}\text { knowledge of } \\
\text { schizophrenia }\end{array}$ & $\begin{array}{l}\text { Knowledge- } \\
\text { Attitude- } \\
\text { Practice } \\
\text { Awareness } \\
\text { Questionnaire }\end{array}$ \\
\hline $\begin{array}{l}\text { Jin et al. } \\
\text { (2006) }\end{array}$ & $\begin{array}{l}\text { South } \\
\text { (Guangdong) }\end{array}$ & 100 & $\mathrm{n} / \mathrm{a}$ & $\mathrm{n} / \mathrm{a}$ & schizophrenia & $\begin{array}{l}\text { caregiver } \\
\text { (family) }\end{array}$ & $\begin{array}{l}\text { knowledge of } \\
\text { mental illness, } \\
\text { treatment, family } \\
\text { involvement }\end{array}$ & self-designed & $\mathrm{n} / \mathrm{a}$ & $\mathrm{n} / \mathrm{a}$ \\
\hline Li (2007) & $\begin{array}{l}\text { South } \\
\text { (Hunan) }\end{array}$ & 196 & $\mathrm{n} / \mathrm{a}$ & $\begin{array}{l}\text { male }(61.7 \%) ; \\
\text { female }(38.3 \%)\end{array}$ & $\begin{array}{l}\text { any mental } \\
\text { illness }\end{array}$ & $\begin{array}{l}\text { caregiver } \\
\text { (family) }\end{array}$ & $\begin{array}{l}\text { knowledge of } \\
\text { mental illness, } \\
\text { treatment, family } \\
\text { involvement, relapse }\end{array}$ & self-designed & $\mathrm{n} / \mathrm{a}$ & $\mathrm{n} / \mathrm{a}$ \\
\hline Li et al. (2006) & $\begin{array}{l}\text { South } \\
\text { (Guangdong) }\end{array}$ & 308 & 46.8 & $\begin{array}{l}\text { male }(56.2 \%) ; \\
\text { female }(43.8 \%)\end{array}$ & $\begin{array}{l}\text { any mental } \\
\text { illness }\end{array}$ & $\begin{array}{l}\text { caregiver } \\
\text { (family) }\end{array}$ & $\begin{array}{l}\text { knowledge of } \\
\text { mental illness, } \\
\text { treatment, family } \\
\text { involvement, } \\
\text { symptoms }\end{array}$ & self-designed & $\mathrm{n} / \mathrm{a}$ & $\mathrm{n} / \mathrm{a}$ \\
\hline Li et al. (2016) & North & patient: & patient: & patient: & bipolar; & patient \& & knowledge \& beliefs & self-designed & $\mathrm{n} / \mathrm{a}$ & $\mathrm{n} / \mathrm{a}$ \\
\hline
\end{tabular}




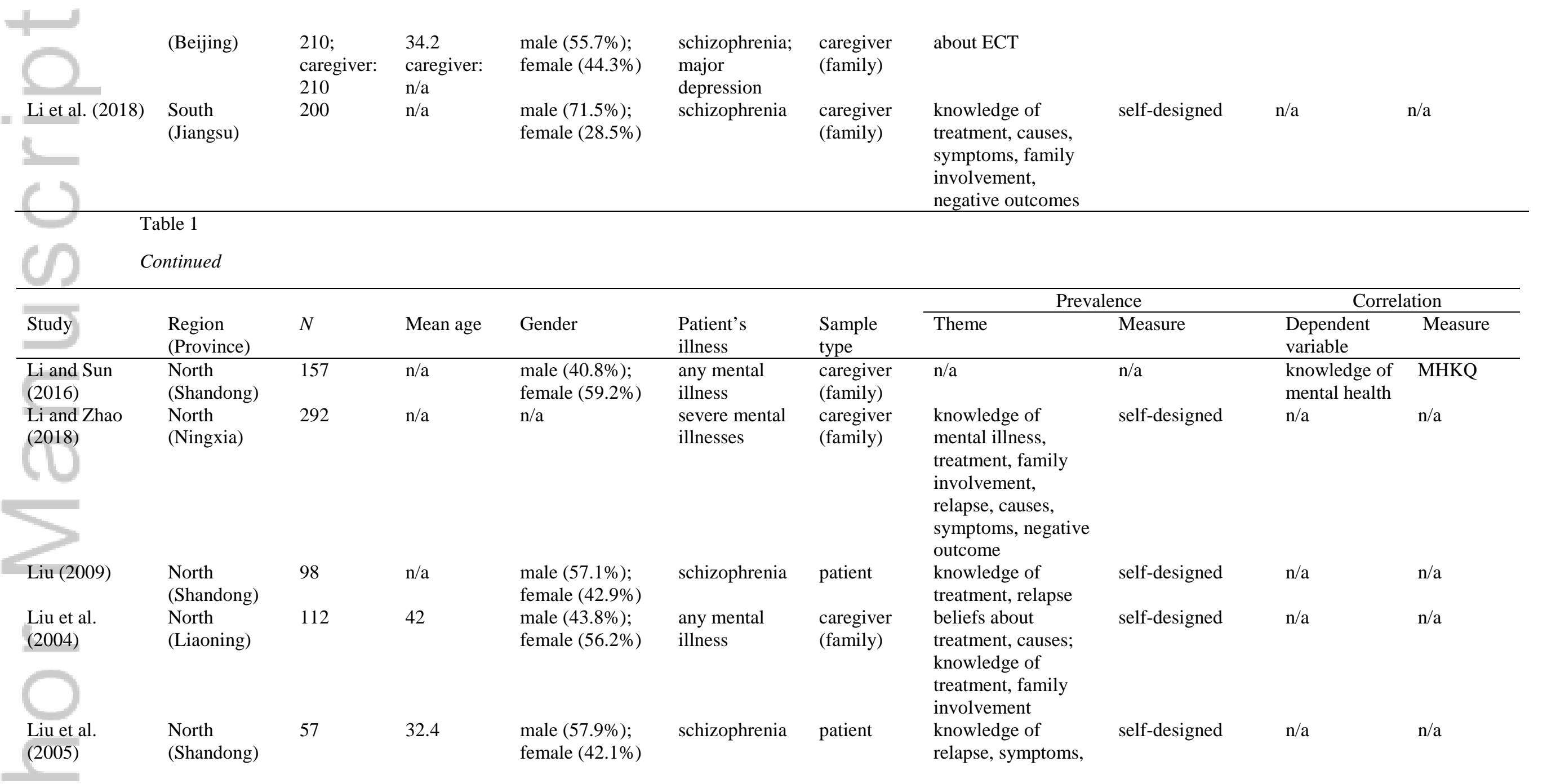




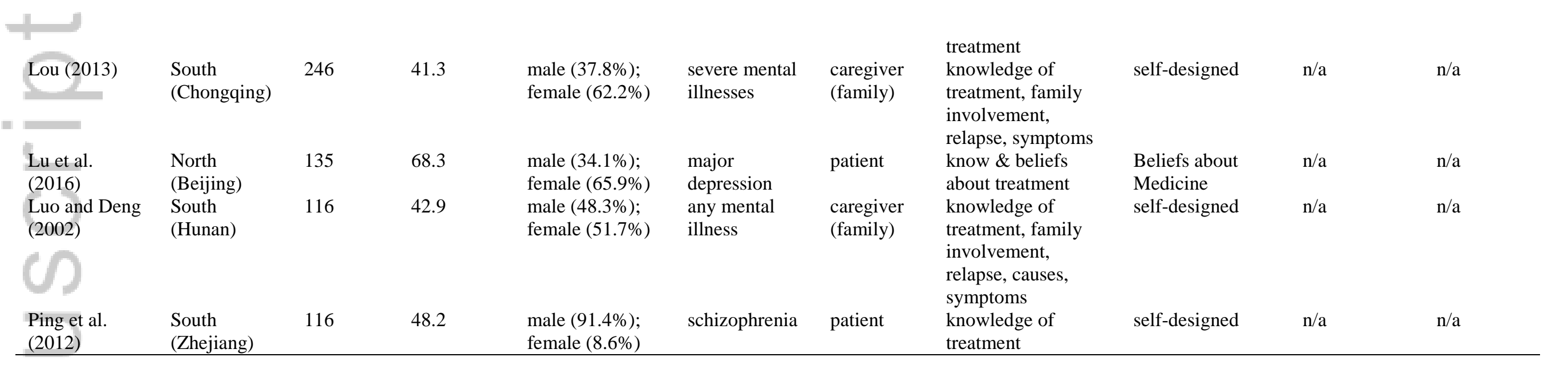

Table 1

\begin{tabular}{|c|c|c|c|c|c|c|c|c|c|c|}
\hline \multirow{2}{*}{ Study } & \multirow[b]{2}{*}{$\begin{array}{l}\text { Region } \\
\text { (Province) }\end{array}$} & \multirow[b]{2}{*}{$N$} & \multirow[b]{2}{*}{ Mean age } & \multirow[b]{2}{*}{ Gender } & \multirow[b]{2}{*}{ Patient's illness } & \multirow[b]{2}{*}{ Sample type } & \multicolumn{2}{|c|}{ Prevalence } & \multicolumn{2}{|c|}{ Correlation } \\
\hline & & & & & & & Theme & Measure & $\begin{array}{l}\text { Dependent } \\
\text { variable }\end{array}$ & Measure \\
\hline $\begin{array}{l}\text { Qu et al. } \\
\text { (2014) }\end{array}$ & $\begin{array}{l}\text { South } \\
\text { (Jiangxi) }\end{array}$ & 300 & $\mathrm{n} / \mathrm{a}$ & $\begin{array}{l}\text { male (62\%); } \\
\text { female }(38 \%)\end{array}$ & schizophrenia & $\begin{array}{l}\text { caregiver } \\
\text { (family or } \\
\text { friend) }\end{array}$ & $\begin{array}{l}\text { knowledge of mental } \\
\text { illness, treatment, } \\
\text { family involvement, } \\
\text { relapse, negative } \\
\text { outcome }\end{array}$ & self-designed & $\mathrm{n} / \mathrm{a}$ & $\mathrm{n} / \mathrm{a}$ \\
\hline $\begin{array}{l}\text { Ran et al. } \\
(2003)\end{array}$ & $\begin{array}{l}\text { South } \\
\text { (Sichuan) }\end{array}$ & 103 & 45.1 & $\begin{array}{l}\text { male }(55.3 \%) ; \\
\text { female }(44.7 \%)\end{array}$ & schizophrenia & $\begin{array}{l}\text { caregiver } \\
\text { (family) }\end{array}$ & $\begin{array}{l}\text { beliefs about causes; } \\
\text { knowledge of } \\
\text { treatment, relapse }\end{array}$ & $\begin{array}{l}\text { Relatives' Beliefs } \\
\text { Scale }\end{array}$ & $\mathrm{n} / \mathrm{a}$ & $\mathrm{n} / \mathrm{a}$ \\
\hline Tan (2005) & $\begin{array}{l}\text { South } \\
\text { (Guangxi) }\end{array}$ & 42 & $\mathrm{n} / \mathrm{a}$ & $\begin{array}{l}\text { male }(31 \%) ; \\
\text { female }(69 \%)\end{array}$ & schizophrenia & patient & $\begin{array}{l}\text { knowledge of } \\
\text { treatment, symptoms }\end{array}$ & self-designed & $\mathrm{n} / \mathrm{a}$ & $\mathrm{n} / \mathrm{a}$ \\
\hline
\end{tabular}




\begin{tabular}{|c|c|c|c|c|c|c|c|c|c|c|}
\hline $\begin{array}{l}\text { Tang et al. } \\
\text { (2015a) }\end{array}$ & $\begin{array}{l}\text { South } \\
\text { (Shanghai) }\end{array}$ & 120 & 58.8 & $\begin{array}{l}\text { male }(39.2 \%) \text {; } \\
\text { female }(60.8 \%)\end{array}$ & schizophrenia & $\begin{array}{l}\text { caregiver } \\
\text { (family) }\end{array}$ & $\begin{array}{l}\text { beliefs about causes; } \\
\text { knowledge of mental } \\
\text { illness, treatment, } \\
\text { family involvement, } \\
\text { symptoms }\end{array}$ & self-designed & $\mathrm{n} / \mathrm{a}$ & $\mathrm{n} / \mathrm{a}$ \\
\hline $\begin{array}{l}\text { Tang et al. } \\
\text { (2016) }\end{array}$ & $\begin{array}{l}\text { North } \\
\text { (Beijing) }\end{array}$ & 107 & $\mathrm{n} / \mathrm{a}$ & $\mathrm{n} / \mathrm{a}$ & schizophrenia & $\begin{array}{l}\text { caregiver } \\
\text { (family) }\end{array}$ & knowledge of treatment & self-designed & $\mathrm{n} / \mathrm{a}$ & $\mathrm{n} / \mathrm{a}$ \\
\hline $\begin{array}{l}\text { Wang et al. } \\
\text { (2012) }\end{array}$ & $\begin{array}{l}\text { North } \\
\text { (Beijing) }\end{array}$ & 192 & 39.5 & $\begin{array}{l}\text { male }(43.2 \%) ; \\
\text { female }(56.8 \%)\end{array}$ & $\begin{array}{l}\text { severe mental } \\
\text { illnesses }\end{array}$ & patient & knowledge of treatment & self-designed & $\mathrm{n} / \mathrm{a}$ & $\mathrm{n} / \mathrm{a}$ \\
\hline $\begin{array}{l}\text { Wang et al. } \\
\text { (2014) }\end{array}$ & $\begin{array}{l}\text { North } \\
\text { (Beijing) }\end{array}$ & 197 & 46.7 & $\begin{array}{l}\text { male }(55.8 \%) \text {; } \\
\text { female }(44.2 \%)\end{array}$ & schizophrenia & $\begin{array}{l}\text { caregiver } \\
\text { (family) }\end{array}$ & $\mathrm{n} / \mathrm{a}$ & $\mathrm{n} / \mathrm{a}$ & $\begin{array}{l}\text { knowledge of } \\
\text { schizophrenia }\end{array}$ & $\begin{array}{l}\text { self- } \\
\text { designed }\end{array}$ \\
\hline $\begin{array}{l}\text { Wang and Yin } \\
\text { (2016) }\end{array}$ & $\begin{array}{l}\text { South } \\
\text { (Jiangsu) }\end{array}$ & 116 & 50.3 & $\begin{array}{l}\text { male }(52.6 \%) ; \\
\text { female }(47.4 \%)\end{array}$ & $\begin{array}{l}\text { any mental } \\
\text { illness }\end{array}$ & $\begin{array}{l}\text { caregiver } \\
\text { (family) }\end{array}$ & $\begin{array}{l}\text { knowledge of mental } \\
\text { illness, treatment, } \\
\text { family involvement, } \\
\text { relapse, causes, } \\
\text { symptoms, negative } \\
\text { outcome }\end{array}$ & self-designed & $\mathrm{n} / \mathrm{a}$ & $\mathrm{n} / \mathrm{a}$ \\
\hline $\begin{array}{l}\text { Wen et al. } \\
\text { (2008) }\end{array}$ & $\begin{array}{l}\text { South } \\
\text { (Guangxi) }\end{array}$ & 120 & 38.5 & $\begin{array}{l}\text { male }(58.3 \%) \text {; } \\
\text { female }(41.7 \%)\end{array}$ & $\begin{array}{l}\text { any mental } \\
\text { illness }\end{array}$ & $\begin{array}{l}\text { caregiver } \\
\text { (family) }\end{array}$ & $\begin{array}{l}\text { knowledge of } \\
\text { treatment, family } \\
\text { involvement, relapse, } \\
\text { causes, symptoms }\end{array}$ & self-designed & $\mathrm{n} / \mathrm{a}$ & $\mathrm{n} / \mathrm{a}$ \\
\hline
\end{tabular}

Table 1

Continued

\begin{tabular}{|c|c|c|c|c|c|c|c|c|c|c|}
\hline \multirow[b]{2}{*}{ Study } & \multirow[b]{2}{*}{$\begin{array}{l}\text { Region } \\
\text { (Province) }\end{array}$} & \multirow[b]{2}{*}{$N$} & \multirow[b]{2}{*}{ Mean age } & \multirow[b]{2}{*}{ Gender } & \multirow[b]{2}{*}{ Patient's illness } & \multirow[b]{2}{*}{ Sample type } & \multicolumn{2}{|c|}{ Prevalence } & \multicolumn{2}{|c|}{ Correlation } \\
\hline & & & & & & & Theme & Measure & $\begin{array}{l}\text { Dependent } \\
\text { variable }\end{array}$ & Measure \\
\hline $\begin{array}{l}\text { Xing and Kang } \\
\text { (2017) }\end{array}$ & $\begin{array}{l}\text { North } \\
\text { (Shandong) }\end{array}$ & 200 & $\mathrm{n} / \mathrm{a}$ & $\mathrm{n} / \mathrm{a}$ & $\begin{array}{l}\text { depression, } \\
\text { anxiety }\end{array}$ & $\begin{array}{l}\text { caregiver } \\
\text { (family) }\end{array}$ & $\begin{array}{l}\text { knowledge of mental } \\
\text { illness, treatment, relapse, } \\
\text { causes, symptoms, }\end{array}$ & self-designed & $\mathrm{n} / \mathrm{a}$ & $n / a$ \\
\hline
\end{tabular}




\begin{tabular}{|c|c|c|c|c|c|c|c|c|c|c|}
\hline $\begin{array}{l}\text { Xing et al. } \\
(2002)\end{array}$ & $\begin{array}{l}\text { North } \\
\text { (Henan) }\end{array}$ & 44 & 43.6 & $\begin{array}{l}\text { male }(56.8 \%) ; \\
\text { female }(43.2 \%)\end{array}$ & schizophrenia & $\begin{array}{l}\text { caregiver } \\
\text { (family) }\end{array}$ & $\begin{array}{l}\text { negative outcome } \\
\text { knowledge of mental } \\
\text { illness, treatment, relapse, } \\
\text { symptoms, negative } \\
\text { outcome }\end{array}$ & self-designed & $\mathrm{n} / \mathrm{a}$ & $\mathrm{n} / \mathrm{a}$ \\
\hline $\begin{array}{l}\text { Yang et al. } \\
(2018)\end{array}$ & $\begin{array}{l}\text { South } \\
\text { (Guangdong) }\end{array}$ & 796 & 52.2 & $\begin{array}{l}\text { male }(58.7 \%) ; \\
\text { female }(41.3 \%)\end{array}$ & $\begin{array}{l}\text { severe mental } \\
\text { illnesses }\end{array}$ & $\begin{array}{l}\text { caregiver } \\
\text { (family) }\end{array}$ & $\begin{array}{l}\text { knowledge of treatment, } \\
\text { family involvement, } \\
\text { relapse }\end{array}$ & self-designed & $\begin{array}{l}\text { knowledge of } \\
\text { the illness } \\
\text { that the } \\
\text { patient has }\end{array}$ & $\begin{array}{l}\text { self- } \\
\text { designed }\end{array}$ \\
\hline $\begin{array}{l}\text { Yu et al. } \\
(2006)\end{array}$ & $\begin{array}{l}\text { North } \\
\text { (Shandong) }\end{array}$ & 100 & 43 & $\begin{array}{l}\text { male }(60 \%) ; \\
\text { female }(40 \%)\end{array}$ & schizophrenia & $\begin{array}{l}\text { caregiver } \\
\text { (family) }\end{array}$ & $\begin{array}{l}\text { knowledge of symptoms, } \\
\text { mental illness, treatment, } \\
\text { family involvement, } \\
\text { relapse }\end{array}$ & self-designed & $\mathrm{n} / \mathrm{a}$ & $\mathrm{n} / \mathrm{a}$ \\
\hline $\begin{array}{l}\text { Zhang et al. } \\
\text { (2011) }\end{array}$ & $\begin{array}{l}\text { South } \\
\text { (Hunan) }\end{array}$ & 306 & 42.9 & $\begin{array}{l}\text { male }(27.1 \%) ; \\
\text { female }(72.9 \%)\end{array}$ & neurotic disorder & patient & knowledge of treatment, & self-designed & $\mathrm{n} / \mathrm{a}$ & $\mathrm{n} / \mathrm{a}$ \\
\hline $\begin{array}{l}\text { Zhang et al. } \\
\text { (2014) }\end{array}$ & $\begin{array}{l}\text { South } \\
\text { (Hainan) }\end{array}$ & 253 & 39 & $\begin{array}{l}\text { male }(42.7 \%) ; \\
\text { female }(57.3 \%)\end{array}$ & schizophrenia & $\begin{array}{l}\text { caregiver } \\
\text { (family) }\end{array}$ & $\begin{array}{l}\text { knowledge of treatment; } \\
\text { help-seeking intention; } \\
\text { beliefs about causes }\end{array}$ & MHKQ & $\begin{array}{l}\text { knowledge of } \\
\text { mental health }\end{array}$ & MHKQ \\
\hline $\begin{array}{l}\text { Zhang et al. } \\
\text { (2018) }\end{array}$ & $\begin{array}{l}\text { North } \\
\text { (Beijing) }\end{array}$ & $\begin{array}{l}\text { patie } \\
\text { nt: } \\
118 ; \\
\text { care } \\
\text { giver } \\
: 118\end{array}$ & $\begin{array}{l}\text { patient: } \\
63.6 \text {; } \\
\text { caregiver: } \\
\text { n/a }\end{array}$ & $\begin{array}{l}\text { patient: male } \\
(28.8 \%) \text {; female } \\
(71.2 \%)\end{array}$ & $\begin{array}{l}\text { schizophrenia; } \\
\text { bipolar; major } \\
\text { depression }\end{array}$ & $\begin{array}{l}\text { patient \& } \\
\text { caregiver } \\
\text { (family or } \\
\text { friend) }\end{array}$ & $\begin{array}{l}\text { knowledge \& beliefs about } \\
\text { treatment }\end{array}$ & self-designed & $\mathrm{n} / \mathrm{a}$ & $\mathrm{n} / \mathrm{a}$ \\
\hline $\begin{array}{l}\text { Zhang et al. } \\
\text { (2010) }\end{array}$ & $\begin{array}{l}\text { South } \\
\text { (Shanghai) }\end{array}$ & 757 & $\mathrm{n} / \mathrm{a}$ & $\begin{array}{l}\text { male }(44.9 \%) ; \\
\text { female }(55.1 \%)\end{array}$ & $\begin{array}{l}\text { any mental } \\
\text { illness }\end{array}$ & $\begin{array}{l}\text { caregiver } \\
\text { (family) }\end{array}$ & $\begin{array}{l}\text { knowledge of mental } \\
\text { illness, treatment, family } \\
\text { involvement, relapse, } \\
\text { causes, symptoms; help- } \\
\text { seeking intention; beliefs } \\
\text { about causes }\end{array}$ & self-designed & $\mathrm{n} / \mathrm{a}$ & $\mathrm{n} / \mathrm{a}$ \\
\hline
\end{tabular}

Table 1 
Continued

\begin{tabular}{|c|c|c|c|c|c|c|c|c|c|c|}
\hline & \multirow[b]{2}{*}{$\begin{array}{l}\text { Region } \\
\text { (Province) }\end{array}$} & \multirow[b]{2}{*}{$N$} & \multirow[b]{2}{*}{ Mean age } & \multirow[b]{2}{*}{ Gender } & \multirow[b]{2}{*}{ Patient's illness } & \multirow[b]{2}{*}{ Sample type } & \multicolumn{2}{|c|}{ Prevalence } & \multicolumn{2}{|c|}{ Correlation } \\
\hline & & & & & & & Theme & Measure & $\begin{array}{l}\text { Dependent } \\
\text { variable }\end{array}$ & Measure \\
\hline $\begin{array}{l}\text { Zhao et al. } \\
\text { (2013) }\end{array}$ & $\begin{array}{l}\text { North } \\
\text { (Beijing) }\end{array}$ & 150 & 52.4 & $\begin{array}{l}\text { male }(40 \%) ; \\
\text { female }(60 \%)\end{array}$ & $\begin{array}{l}\text { severe mental } \\
\text { illnesses }\end{array}$ & $\begin{array}{l}\text { caregiver } \\
\text { (family) }\end{array}$ & $\mathrm{n} / \mathrm{a}$ & $\mathrm{n} / \mathrm{a}$ & $\begin{array}{l}\text { knowledge of } \\
\text { recovery; } \\
\text { knowledge of } \\
\text { mental health }\end{array}$ & $\begin{array}{l}\text { self- } \\
\text { designed }\end{array}$ \\
\hline $\begin{array}{l}\text { Zhao and } \\
\text { Liang } \\
\text { (2005) }\end{array}$ & $\begin{array}{l}\text { South } \\
\text { (Guangdong) }\end{array}$ & 110 & 38.5 & $\begin{array}{l}\text { male }(59.1 \%) \text {; } \\
\text { female } \\
(40.9 \%)\end{array}$ & $\begin{array}{l}\text { any mental } \\
\text { illness }\end{array}$ & $\begin{array}{l}\text { caregiver } \\
\text { (family) }\end{array}$ & $\begin{array}{l}\text { knowledge of } \\
\text { treatment, family } \\
\text { involvement, relapse, } \\
\text { causes, symptoms }\end{array}$ & self-designed & $\mathrm{n} / \mathrm{a}$ & $\mathrm{n} / \mathrm{a}$ \\
\hline $\begin{array}{l}\text { Zhou et al. } \\
\text { (2016) }\end{array}$ & $\begin{array}{l}\text { South } \\
\text { (Hunan) }\end{array}$ & 500 & 33.4 & $\begin{array}{l}\text { male }(55 \%) ; \\
\text { female }(45 \%)\end{array}$ & schizophrenia & patient & $\begin{array}{l}\text { beliefs about } \\
\text { treatment }\end{array}$ & self-designed & $\begin{array}{l}\text { beliefs about } \\
\text { antipsychotics }\end{array}$ & $\begin{array}{l}\text { self- } \\
\text { designed }\end{array}$ \\
\hline Zhu (2009) & $\begin{array}{l}\text { South } \\
\text { (Guangdong) }\end{array}$ & 166 & $\mathrm{n} / \mathrm{a}$ & $\begin{array}{l}\text { male }(58.4 \%) \text {; } \\
\text { female } \\
(41.6 \%)\end{array}$ & $\begin{array}{l}\text { any mental } \\
\text { illness }\end{array}$ & $\begin{array}{l}\text { caregiver } \\
\text { (family) }\end{array}$ & $\begin{array}{l}\text { knowledge of mental } \\
\text { illness, treatment, } \\
\text { family involvement, } \\
\text { relapse }\end{array}$ & self-designed & $\mathrm{n} / \mathrm{a}$ & $\mathrm{n} / \mathrm{a}$ \\
\hline $\begin{array}{l}\text { Zhu et al. } \\
\text { (2018) }\end{array}$ & $\begin{array}{l}\text { South } \\
\text { (Guangdong) }\end{array}$ & 298 & 52.4 & $\begin{array}{l}\text { male }(53.4 \%) \text {; } \\
\text { female } \\
(46.6 \%)\end{array}$ & $\begin{array}{l}\text { severe mental } \\
\text { illnesses }\end{array}$ & $\begin{array}{l}\text { caregiver } \\
\text { (family) }\end{array}$ & $\begin{array}{l}\text { help-seeking } \\
\text { intention; beliefs } \\
\text { about causes; } \\
\text { knowledge of } \\
\text { treatment }\end{array}$ & MHKQ & $\begin{array}{l}\text { knowledge of } \\
\text { mental health }\end{array}$ & MHKQ \\
\hline
\end{tabular}

Note. severe mental illnesses include schizophrenia, schizoaffective disorder, persistent delusional disorder, bipolar disorder, mental illness associated with epilepsy, and intellectual disability (National Health Commission of the People's Republic of China, 2013a).

This article is protected by copyright. All rights reserved. 
Knowledge of relapse - severe mental illnesses

\begin{tabular}{|c|c|c|c|c|c|c|c|c|c|c|}
\hline signs of relapse & 1 & 400 & 44.5 & 39.7 & 49.4 & - & - & - & - & (Chen et al., 2019) \\
\hline dealing with relapse & 1 & 400 & 90.5 & 87.2 & 93 & - & - & - & - & (Chen et al., 2019) \\
\hline \multicolumn{11}{|l|}{ Table 2} \\
\hline \multicolumn{11}{|l|}{ Continued } \\
\hline \multirow[b]{2}{*}{ Theme } & \multirow[b]{2}{*}{$k$} & \multirow[b]{2}{*}{$N$} & \multirow[b]{2}{*}{$\begin{array}{l}\text { Rate } \\
(\%)\end{array}$} & \multicolumn{2}{|c|}{ 95\%CI (\%) } & \multirow[b]{2}{*}{$I^{2}(\%)$} & \multicolumn{3}{|c|}{ Effect of region } & \multirow[b]{2}{*}{ References } \\
\hline & & & & lower & upper & & $Q$ & $p$ & $k$ & \\
\hline \multicolumn{11}{|l|}{ Knowledge of treatment -ECT } \\
\hline ECT is safe & 2 & 328 & 64 & 58.7 & 69.1 & 0 & - & - & $2 \mathrm{~N}$ & (Li et al., 2016; Zhang et al., 2018) \\
\hline ECT does not generate fear & 2 & 328 & 56.5 & 51.1 & 61.8 & 0 & - & - & $2 \mathrm{~N}$ & (Li et al., 2016; Zhang et al., 2018) \\
\hline I do not think ECT is more dangerous than drugs & 2 & 328 & 50.2 & 44.8 & 55.6 & 0 & - & - & $2 \mathrm{~N}$ & (Li et al., 2016; Zhang et al., 2018) \\
\hline ECT is not dangerous and should be used & 2 & 328 & 65.6 & 52.4 & 76.7 & 80.3 & - & - & $2 \mathrm{~N}$ & (Li et al., 2016; Zhang et al., 2018) \\
\hline $\begin{array}{l}\text { ECT is used for people who need it (e.g., critically ill } \\
\text { patients) }\end{array}$ & 2 & 328 & 44.4 & 31.4 & 58.3 & 83.3 & - & - & $2 \mathrm{~N}$ & (Li et al., 2016; Zhang et al., 2018) \\
\hline ECT should not be the last resort & 2 & 328 & 41.1 & 35.9 & 46.5 & 0 & - & - & $2 \mathrm{~N}$ & (Li et al., 2016; Zhang et al., 2018) \\
\hline ECT is not used to punish patients & 2 & 328 & 78.1 & 70 & 84.5 & 57.4 & - & - & $2 \mathrm{~N}$ & (Li et al., 2016; Zhang et al., 2018) \\
\hline \multicolumn{11}{|l|}{ Knowledge of treatment - medication (mental illness in general) } \\
\hline medicine adherence is important & 1 & 198 & 9.1 & 5.8 & 14 & - & - & - & - & (Chen et al., 2011) \\
\hline $\begin{array}{l}\text { risk of stopping taking medications or increasing the dose } \\
\text { without permission }\end{array}$ & 1 & 198 & 3.5 & 1.7 & 7.2 & - & - & - & - & (Chen et al., 2011) \\
\hline therapeutic and side effects of medications & 1 & 198 & 7.6 & 4.6 & 12.2 & - & - & - & - & (Chen et al., 2011) \\
\hline $\begin{array}{l}\text { one should ask professionals' help with the side effects of } \\
\text { medications }\end{array}$ & 1 & 198 & 8.6 & 5.4 & 13.4 & - & - & - & - & (Chen et al., 2011) \\
\hline know about the antidepressant I am taking & 1 & 135 & 41.5 & 33.5 & 50 & - & - & - & - & (Lu et al., 2016) \\
\hline
\end{tabular}


Knowledge of treatment - available services

know about available community mental health services

Knowledge of treatment - schizophrenia

therapeutic effects of the medication

name of the medication

shape and colour of the medication

dose

one should not increase or decrease the dose without

permission

one should not take medications intermittently

one should not stop taking medications on his/her own

decision

side effects of the medication

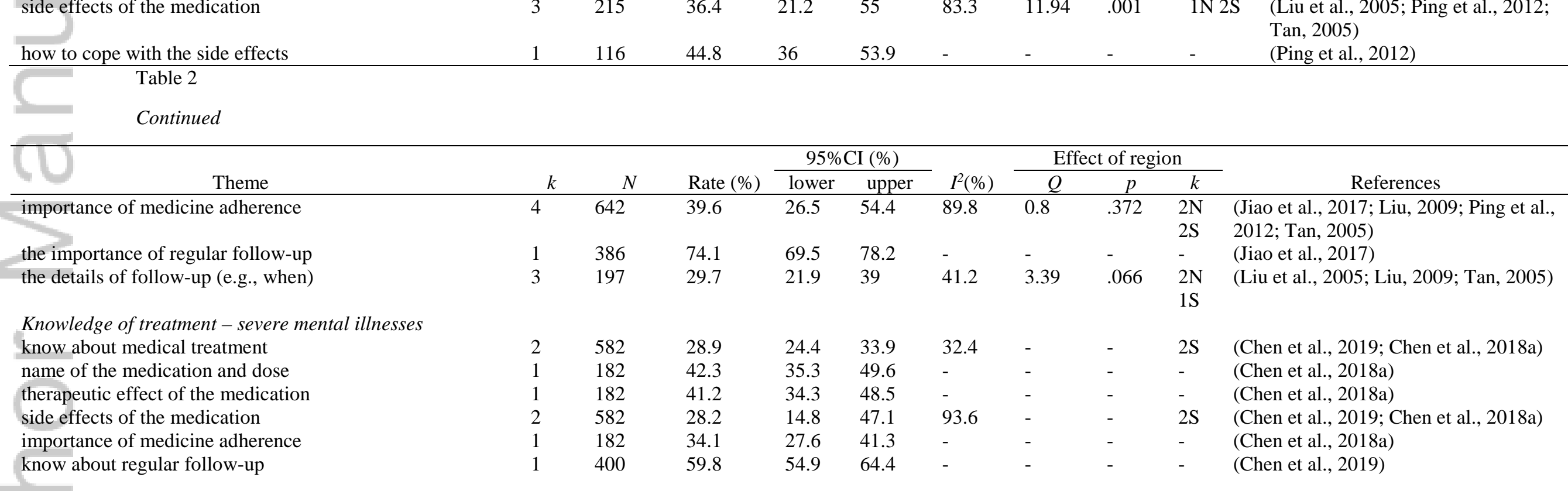

This article is protected by copyright. All rights reserved. 
Knowledge of treatment - neurotic disorder

professional services should be sought

Knowledge of family involvement - schizophrenia

family members' negative attitudes can influence patients'

conditions

Knowledge of family involvement - severe mental illnesses how to respond to negative situations

how to provide care at home

Beliefs about causes - schizophrenia

abnormal brain structure and function

abnormal body structure and function

ghosts

introversion

interpersonal relationship issue

negative childhood experiences

physical and intellectual development issue

family environment

heredity

stress

viral infection

substance use

\begin{tabular}{|c|c|c|c|c|c|c|c|c|c|}
\hline 1 & 306 & 33 & 28 & 38.5 & - & - & - & - & (Zhang et al., 2011) \\
\hline 1 & 386 & 54 & 49 & 58.9 & - & - & - & - & (Jiao et al., 2017) \\
\hline 1 & 400 & 47.2 & 42.4 & 52.2 & - & - & - & - & (Chen et al., 2019) \\
\hline 1 & 400 & 42 & 37.3 & 46.9 & - & - & - & - & (Chen et al., 2019) \\
\hline 1 & 386 & 42 & 37.2 & 47 & - & - & - & - & (Jiao et al., 2017) \\
\hline 1 & 386 & 61.7 & 56.7 & 66.4 & - & - & - & - & (Jiao et al., 2017) \\
\hline 1 & 386 & 43 & 38.1 & 48 & - & - & - & - & (Jiao et al., 2017) \\
\hline 1 & 386 & 68.1 & 63.3 & 72.6 & - & - & - & - & (Jiao et al., 2017) \\
\hline 1 & 386 & 43 & 38.1 & 48 & - & - & - & - & (Jiao et al., 2017) \\
\hline 1 & 386 & 18.1 & 14.6 & 22.3 & - & - & - & - & (Jiao et al., 2017) \\
\hline 1 & 386 & 9.4 & 6.9 & 12.7 & - & - & - & - & (Jiao et al., 2017) \\
\hline 1 & 386 & 32.9 & 28.4 & 37.7 & - & - & - & - & (Jiao et al., 2017) \\
\hline 1 & 386 & 19.1 & 15.5 & 23.3 & - & - & - & - & (Jiao et al., 2017) \\
\hline 1 & 386 & 91.7 & 88.5 & 94.1 & - & - & - & - & (Jiao et al., 2017) \\
\hline 1 & 386 & 4.1 & 2.5 & 6.6 & - & - & - & - & (Jiao et al., 2017) \\
\hline 1 & 386 & 10.1 & 7.5 & 13.5 & - & - & - & - & (Jiao et al., 2017) \\
\hline
\end{tabular}

Table 2

Continued

\begin{tabular}{|c|c|c|c|c|c|c|c|c|c|c|c|}
\hline \multirow[t]{2}{*}{ 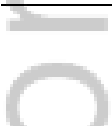 } & \multirow[b]{2}{*}{ Theme } & \multirow[b]{2}{*}{$k$} & \multirow[b]{2}{*}{$N$} & \multirow[b]{2}{*}{$\begin{array}{l}\text { Rate } \\
(\%)\end{array}$} & \multicolumn{2}{|c|}{ 95\%CI (\%) } & \multirow[b]{2}{*}{$I^{2}(\%)$} & \multicolumn{3}{|c|}{ Effect of region } & \multirow[b]{2}{*}{ References } \\
\hline & & & & & lower & upper & & $Q$ & $p$ & $k$ & \\
\hline \multicolumn{12}{|c|}{ Beliefs about treatment - ECT } \\
\hline \multicolumn{2}{|c|}{ ECT is beneficial } & 2 & 328 & 68.4 & 63.1 & 73.2 & 0 & - & - & $2 \mathrm{~N}$ & (Li et al., 2016; Zhang et al., 2018) \\
\hline \multicolumn{2}{|c|}{ ECT is more effective than drugs } & 2 & 328 & 61.9 & 54.1 & 69.2 & 48.3 & - & - & $2 \mathrm{~N}$ & (Li et al., 2016; Zhang et al., 2018) \\
\hline
\end{tabular}

This article is protected by copyright. All rights reserved. 


\begin{tabular}{|c|c|c|c|c|c|c|c|c|c|c|}
\hline the effect of ECT is more rapid than drugs & 2 & 328 & 64.4 & 59 & 69.4 & 0 & - & - & $2 \mathrm{~N}$ & (Li et al., 2016; Zhang et al., 2018) \\
\hline would like to receive ECT again & 2 & 328 & 53.4 & 47.9 & 58.7 & 0 & - & - & $2 \mathrm{~N}$ & (Li et al., 2016; Zhang et al., 2018) \\
\hline \multicolumn{11}{|l|}{ Beliefs about treatment - medication } \\
\hline medical treatment is key to treating mental illness & 1 & 198 & 8.1 & 5 & 12.8 & - & - & - & - & (Chen et al., 2011) \\
\hline medical treatment is helpful & 1 & 500 & 64.2 & 59.9 & 68.3 & - & - & - & - & (Zhou et al., 2016) \\
\hline antidepressants are helpful & 1 & 135 & 66.5 & 58.1 & 73.9 & - & - & - & - & (Lu et al., 2016) \\
\hline worry about the long-term effects of antidepressants & 1 & 135 & 75.6 & 67.7 & 82.1 & - & - & - & - & (Lu et al., 2016) \\
\hline worry about becoming too dependent upon antidepressants & 1 & 135 & 55.6 & 47.1 & 63.7 & - & - & - & - & (Lu et al., 2016) \\
\hline $\begin{array}{l}\text { Beliefs about treatment - schizophrenia } \\
\text { medical treatment is the main treatment method for } \\
\text { schizophrenia }\end{array}$ & 1 & 386 & 72.8 & 68.1 & 77 & - & - & - & - & (Jiao et al., 2017) \\
\hline $\begin{array}{l}\text { living with family members can improve the } \\
\text { symptoms }\end{array}$ & 1 & 386 & 50.2 & 45.2 & 55.2 & - & - & - & - & (Jiao et al., 2017) \\
\hline $\begin{array}{l}\text { actively engaging in the communication with family } \\
\text { members can improve the symptoms }\end{array}$ & 1 & 386 & 48.1 & 43.2 & 53.1 & - & - & - & - & (Jiao et al., 2017) \\
\hline doing simple housework can improve the symptoms & 1 & 386 & 50.9 & 45.9 & 55.9 & - & - & - & - & (Jiao et al., 2017) \\
\hline $\begin{array}{l}\text { keeping contact with friends and relatives can improve the } \\
\text { symptoms }\end{array}$ & 1 & 386 & 52.9 & 47.9 & 57.8 & - & - & - & - & (Jiao et al., 2017) \\
\hline $\begin{array}{l}\text { keeping contact with mental health professionals can } \\
\text { improve the symptoms }\end{array}$ & 1 & 386 & 31.9 & 27.4 & 36.7 & - & - & - & - & (Jiao et al., 2017) \\
\hline participating in social events can improve symptoms & 1 & 386 & 42 & 37.2 & 47 & - & - & - & - & (Jiao et al., 2017) \\
\hline rehabilitation training is helpful & 1 & 386 & 13 & 10 & 16.7 & - & - & - & - & (Jiao et al., 2017) \\
\hline
\end{tabular}

This article is protected by copyright. All rights reserved. 
Table 3

Correlates of mental health literacy in patients $(k=4)$

\begin{tabular}{|c|c|c|c|c|c|c|c|c|c|c|}
\hline \multirow{2}{*}{\multicolumn{2}{|c|}{ Dependent Variable (measure) }} & \multirow[b]{2}{*}{ Independent variable (measure) } & \multirow[b]{2}{*}{$k$} & \multirow[b]{2}{*}{$N$} & \multirow[b]{2}{*}{$r$} & \multirow[b]{2}{*}{$p$} & \multicolumn{2}{|c|}{$95 \% \mathrm{CI}$} & \multirow[t]{2}{*}{$I^{2}(\%)$} & \multirow[t]{2}{*}{ References } \\
\hline & & & & & & & lower & upper & & \\
\hline \multirow{19}{*}{\multicolumn{2}{|c|}{$\begin{array}{l}\text { beliefs about antipsychotic medications (“do you } \\
\text { think you need antipsychotic medication” "did } \\
\text { medication treatment help”) }\end{array}$}} & single & 1 & 500 & 0.07 & .114 & -0.02 & 0.16 & - & (Zhou et al., 2016) \\
\hline & & rural residence & 1 & 500 & 0.08 & .079 & -0.01 & 0.17 & - & (Zhou et al., 2016) \\
\hline & & unemployed & 1 & 500 & 0.02 & .735 & -0.07 & 0.10 & - & (Zhou et al., 2016) \\
\hline & & age & 1 & 500 & -0.02 & .702 & -0.11 & 0.07 & - & (Zhou et al., 2016) \\
\hline & & age of onset & 1 & 500 & 0.08 & .067 & -0.01 & 0.17 & - & (Zhou et al., 2016) \\
\hline & & education & 1 & 500 & 0.004 & .922 & -0.08 & 0.09 & - & (Zhou et al., 2016) \\
\hline & & length of illness & 1 & 500 & -0.1 & .030 & -0.18 & -0.01 & - & (Zhou et al., 2016) \\
\hline & & number of psychiatric hospitalizations & 1 & 500 & -0.06 & .184 & -0.15 & 0.03 & - & (Zhou et al., 2016) \\
\hline & & illness awareness (ITAQ) & 1 & 500 & -0.38 & $<.001$ & -0.45 & -0.30 & - & (Zhou et al., 2016) \\
\hline & & medication knowledge (ITAQ) & 1 & 500 & -0.49 & $<.001$ & -0.55 & -0.42 & - & (Zhou et al., 2016) \\
\hline & & somatization (SCL-90) & 1 & 500 & 0.09 & .040 & 0.004 & 0.18 & - & (Zhou et al., 2016) \\
\hline & & obsession-compulsion (SCL-90) & 1 & 500 & 0.06 & .216 & -0.03 & 0.14 & - & (Zhou et al., 2016) \\
\hline & & interpersonal sensitivity (SCL-90) & 1 & 500 & 0.12 & .006 & 0.04 & 0.21 & - & (Zhou et al., 2016) \\
\hline & & depression (SCL-90) & 1 & 500 & 0.09 & .045 & 0.002 & 0.18 & - & (Zhou et al., 2016) \\
\hline & & anxiety (SCL-90) & 1 & 500 & 0.10 & .025 & 0.01 & 0.19 & - & (Zhou et al., 2016) \\
\hline & & hostility (SCL-90) & 1 & 500 & 0.15 & .001 & 0.06 & 0.23 & - & (Zhou et al., 2016) \\
\hline & & phobic anxiety (SCL-90) & 1 & 500 & 0.09 & .038 & 0.01 & 0.18 & - & (Zhou et al., 2016) \\
\hline & & paranoid ideation (SCL-90) & 1 & 500 & 0.13 & .004 & 0.04 & 0.22 & - & (Zhou et al., 2016) \\
\hline & & psychoticism (SCL-90) & 1 & 500 & 0.10 & .023 & 0.01 & 0.19 & - & (Zhou et al., 2016) \\
\hline \multirow{3}{*}{\multicolumn{2}{|c|}{$\begin{array}{l}\text { knowledge of the medication that the patient is taking } \\
\text { (self-designed survey) }\end{array}$}} & beliefs about taking medications (Beliefs about & 1 & 182 & 0.44 & $<.001$ & 0.31 & 0.55 & - & (Chen et al., 2018a) \\
\hline & & Taking Medications Questionnaire) & & & & & & & & \\
\hline & & $\begin{array}{l}\text { medicine adherence (“are you willing to take } \\
\text { medications as prescribed”) }\end{array}$ & 1 & 182 & -0.35 & $<.001$ & -0.47 & -0.21 & - & (Chen et al., 2018a) \\
\hline \multirow{3}{*}{\multicolumn{2}{|c|}{ knowledge of mental illness (self-designed survey) }} & gender & 1 & 400 & 0.20 & $<.001$ & 0.10 & 0.29 & - & (Chen et al., 2019) \\
\hline & & age & 1 & 400 & 0.77 & $<.001$ & 0.73 & 0.81 & - & (Chen et al., 2019) \\
\hline & & education & 1 & 400 & 0.65 & $<.001$ & 0.59 & 0.70 & - & (Chen et al., 2019) \\
\hline
\end{tabular}

This article is protected by copyright. All rights reserved. 


\begin{tabular}{|c|c|c|c|c|c|c|c|c|c|}
\hline $\begin{array}{l}\text { knowledge of schizophrenia (Knowledge-Attitude- } \\
\text { Practice Awareness Questionnaire for Schizophrenia) }\end{array}$ & gender & 1 & 386 & 0.08 & .108 & -0.02 & 0.18 & - & (Jiao et al., 2017) \\
\hline 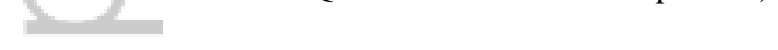 & residential area & 1 & 386 & 0.14 & .007 & 0.04 & 0.23 & - & (Jiao et al., 2017) \\
\hline 1 & marital status & 1 & 386 & 0.14 & .006 & 0.04 & 0.24 & - & (Jiao et al., 2017) \\
\hline a & education & 1 & 386 & 0.38 & $<.001$ & 0.29 & 0.46 & - & (Jiao et al., 2017) \\
\hline 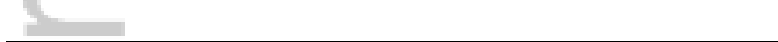 & occupation & 1 & 386 & 0.38 & $<.001$ & 0.29 & 0.46 & - & (Jiao et al., 2017) \\
\hline
\end{tabular}

Note. ITAQ = Insight and Treatment Attitudes Questionnaire; SCL-90 = Symptom Checklist-90.

This article is protected by copyright. All rights reserved. 
Table 4

Prevalence of each theme relating to knowledge or beliefs about mental illness for caregivers

\begin{tabular}{|c|c|c|c|c|c|c|c|c|c|c|}
\hline \multirow{2}{*}{+2} & \multirow[b]{2}{*}{$k$} & \multirow[b]{2}{*}{$N$} & \multirow[b]{2}{*}{$\begin{array}{l}\text { Rate } \\
(\%)\end{array}$} & \multicolumn{2}{|c|}{ 95\%CI (\%) } & \multirow[b]{2}{*}{$I^{2}(\%)$} & \multicolumn{3}{|c|}{ Effect of region } & \multirow[b]{2}{*}{ References } \\
\hline & & & & lower & upper & & $Q$ & $p$ & $k$ & \\
\hline \multicolumn{11}{|l|}{ Recognition } \\
\hline depression & 1 & 202 & 43.6 & 36.9 & 50.5 & - & - & - & - & (Chen et al., 2017) \\
\hline schizophrenia & 1 & 200 & 28.5 & 22.7 & 35.1 & - & - & - & - & (Chen et al., 2017) \\
\hline GAD & 1 & 204 & 18.1 & 13.4 & 24 & - & - & - & - & (Chen et al., 2018b) \\
\hline \multicolumn{11}{|l|}{ Knowledge of mental illness } \\
\hline know the name of the disorder that the patient has (schizophrenia) & 4 & 620 & 77.5 & 51.9 & 91.6 & 96.5 & 5.28 & .022 & $\begin{array}{l}1 \mathrm{~N} \\
3 \mathrm{~S}\end{array}$ & $\begin{array}{l}\text { (Jin et al., 2006; Qu et al., 2014; Tang et } \\
\text { al., 2015a; Yu et al., 2006) }\end{array}$ \\
\hline know about schizophrenia & 4 & 902 & 15.4 & 3 & 51.6 & 98.3 & 0.01 & .934 & $\begin{array}{l}1 \mathrm{~N} \\
3 \mathrm{~S}\end{array}$ & $\begin{array}{l}\text { (Chen et al., 2008; Ding \& Chen, 2012; } \\
\text { Li et al., 2018; Xing et al., 2002) }\end{array}$ \\
\hline know the name of the disorder that the patient has (severe mental illnesses) & 1 & 292 & 46.6 & 40.9 & 52.3 & - & - & - & - & (Li \& Zhao, 2018) \\
\hline know the categories of severe mental illnesses & 1 & 150 & 29.3 & 22.6 & 37.1 & - & - & - & - & (Huang, 2013) \\
\hline know the name of the disorder that the patient has (depression or anxiety) & 1 & 200 & 66 & 59.2 & 72.2 & - & - & - & - & (Xing \& Kang, 2017) \\
\hline know the nature of mental illness & 3 & 441 & 42.4 & 33.6 & 51.7 & 72.2 & - & - & $3 S$ & (Gao et al., 2004; Li, 2007; Zhu, 2009) \\
\hline know the name of the disorder that the patient has (any mental illness) & 3 & 1,181 & 71.5 & 50.7 & 86 & 97.3 & - & - & $3 S$ & $\begin{array}{l}\text { (Li et al., 2006; Wang \& Yin, 2016; } \\
\text { Zhang et al., 2010) }\end{array}$ \\
\hline \multicolumn{11}{|l|}{ Knowledge of causes } \\
\hline know about the causes of schizophrenia & 2 & 400 & 6.8 & 2.6 & 16.6 & 82.9 & - & - & $2 \mathrm{~S}$ & (Chen et al., 2008; Li et al., 2018) \\
\hline effect of heredity on schizophrenia & 1 & 458 & 37.6 & 33.2 & 42.1 & - & - & - & - & (Ding \& Chen, 2012) \\
\hline know about the causes of severe mental illnesses & 2 & 442 & 33.3 & 28.3 & 38.7 & 26.3 & 0.17 & .685 & $\begin{array}{l}1 \mathrm{~N} \\
1 \mathrm{~S}\end{array}$ & (Huang, 2013; Li \& Zhao, 2018) \\
\hline know about the causes of depression or anxiety & 1 & 200 & 3.5 & 1.7 & 7.2 & - & - & - & - & (Xing \& Kang, 2017) \\
\hline know about the causes of the illness & 5 & 742 & 27.7 & 21 & 35.7 & 79.4 & - & - & $5 S$ & $\begin{array}{l}\text { (Chen \& Liu, 2006; Luo \& Deng, 2002; } \\
\text { Wang \& Yin, 2016; Wen et al., 2008; } \\
\text { Zhao \& Liang, 2005) }\end{array}$ \\
\hline $\begin{array}{l}\text { binge drinking can cause mental health issues } \\
\text { Knowledge of signs and symptoms }\end{array}$ & 1 & 757 & 20.2 & 17.5 & 23.2 & - & - & - & - & (Zhang et al., 2010) \\
\hline know about the symptoms of schizophrenia & 5 & 922 & 18.5 & 6.5 & 42.7 & 96.9 & 0.31 & .576 & $\begin{array}{l}2 \mathrm{~N} \\
3 \mathrm{~S}\end{array}$ & $\begin{array}{l}\text { (Ding \& Chen, 2012; Li et al., 2018; } \\
\text { Tang et al., 2015a; Xing et al., 2002; Yu }\end{array}$ \\
\hline
\end{tabular}


know about the possibility of relapse

know about the signs of relapse

know about how to prevent relapse

relapse can be prevented by relieving stress

medical treatment is the key to reduce the risk of relapse

keeping the patient at home will not prevent relapse

Knowledge of relapse - severe mental illnesses

know about the signs of relapse

know about how to recognize the signs

know about how to prevent relapse

know about how to cope with relapse

Knowledge of relapse - depression or anxiety

know about the signs of relapse

$\begin{array}{llllllllll}1 & 300 & 32 & 27 & 37.5 & - & - & - & - & \text { (Qu et al., 2014) } \\ 2 & 558 & 41.8 & 30.5 & 54 & 79.4 & 2.63 & .105 & 1 \mathrm{~N} & \begin{array}{l}\text { (Ding \& Chen, 2012; Yu et al., 2006) } \\ 1\end{array} \\ 1 & 44 & 9.1 & 3.5 & 21.8 & - & - & - & - & \text { (Xing et al., 2002) } \\ 1 & 75 & 65.3 & 53.9 & 75.2 & - & - & - & - & \text { (Ran et al., 2003) } \\ 1 & 458 & 57.6 & 53.1 & 62.1 & - & - & - & - & \text { (Ding \& Chen, 2012) } \\ 1 & 458 & 53.9 & 49.3 & 58.4 & - & - & - & - & \text { (Ding \& Chen, 2012) } \\ & & & & & & & & & \\ 1 & 150 & 46 & 38.2 & 54 & - & - & - & - & \text { (Huang, 2013) } \\ 1 & 292 & 22.3 & 17.9 & 27.4 & - & - & - & - & \text { (Li \& Zhao, 2018) } \\ 1 & 246 & 6.5 & 4 & 10.3 & - & - & - & - & \text { (Lou, 2013) } \\ 1 & 796 & 63.1 & 59.7 & 66.4 & - & - & - & - & \text { (Yang et al., 2018) } \\ & & & & & & & & & \text { (Xing \& Kang, 2017) } \\ 1 & 200 & 33.5 & 27.3 & 40.3 & - & - & - & - & \end{array}$

Table 4

Continued

\begin{tabular}{|c|c|c|c|c|c|c|c|c|c|c|}
\hline \multirow[b]{2}{*}{ Theme } & \multirow[b]{2}{*}{$k$} & \multirow[b]{2}{*}{$N$} & \multirow[b]{2}{*}{$\begin{array}{c}\text { Rate } \\
(\%)\end{array}$} & \multicolumn{2}{|c|}{ 95\%CI (\%) } & \multirow[b]{2}{*}{$I^{2}(\%)$} & \multicolumn{3}{|c|}{ Effect of region } & \multirow[b]{2}{*}{ References } \\
\hline & & & & lower & upper & & $Q$ & $p$ & $k$ & \\
\hline \multicolumn{11}{|l|}{ Knowledge of treatment - mental illness in general } \\
\hline most mental disorders can be cured & 3 & 1,308 & 67 & 38.4 & 86.8 & 98.5 & - & - & $3 S$ & $\begin{array}{l}\text { (Zhang et al., 2014; Zhang et al., 2010; } \\
\text { Zhu et al., 2018) }\end{array}$ \\
\hline things one should pay attention to after the onset of the illness & 1 & 116 & 37.1 & 28.8 & 46.2 & - & - & - & - & (Wang \& Yin, 2016) \\
\hline importance of receiving professional help timely & 1 & 804 & 37.1 & 33.8 & 40.5 & - & - & - & - & (Chen \& Tan, 2010) \\
\hline treatment that the patient has received & 3 & 346 & 37 & 30.4 & 44.1 & 45.2 & - & - & $3 S$ & $\begin{array}{l}\text { (Wang \& Yin, 2016; Wen et al., 2008; } \\
\text { Zhao \& Liang, 2005) }\end{array}$ \\
\hline know about family therapy & 1 & 112 & 14.2 & 8.9 & 22 & - & - & - & - & (Liu et al., 2004) \\
\hline know about psychotherapy & 2 & 230 & 23.4 & 18.4 & 29.4 & 0 & - & - & $2 \mathrm{~S}$ & (Wen et al., 2008; Zhao \& Liang, 2005) \\
\hline know about rehabilitation & 2 & 230 & 28.2 & 22.8 & 34.4 & 0 & - & - & $2 S$ & (Wen et al., 2008; Zhao \& Liang, 2005) \\
\hline
\end{tabular}

This article is protected by copyright. All rights reserved. 
name of the medication that the patient is taking

therapeutic and side effects of the medication

therapeutic effects of the medication

side effects of the medication

know about how to cope with the side effects

know about methods, side effects and precautions of medical treatment

know about rational use of medications

seeking help from the doctor when the patient refuses to take medications

importance of medicine adherence

length of duration for keeping the patient on medications

know about regular follow-up

importance of regular follow-up

$4 \quad 1,2$

3987

2424

1308

2226

$2 \quad 362$

1280

1757

$9 \quad 2,661$
41

35.8

$\begin{array}{ll}13.2 & 0.8\end{array}$

$2.9 \quad 1.5$

$24.7 \quad 16.1$

$17.6 \quad 6.1$

$14.3 \quad 10.7$

$81.8 \quad 78.9$

$41.1 \quad 24.3$
46.5

74.6

5.5

36

41.4

18.9

84.4

60.1

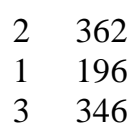

$18.1 \quad 7.4$

$4.6 \quad 2.4$

38.216 .1

8.6

66.6

knowledge of treatment - schizophrenia

schizophrenia can be treated

know about treatment methods

know about treatment outcomes

name of the medication that the patient is taking

Table 4

Continued

\begin{tabular}{|c|c|c|c|c|c|c|c|c|c|c|}
\hline & \multirow[b]{2}{*}{$k$} & \multirow[b]{2}{*}{$N$} & \multirow[b]{2}{*}{$\begin{array}{c}\text { Rate } \\
(\%)\end{array}$} & \multicolumn{2}{|c|}{ 95\%CI (\%) } & \multirow[b]{2}{*}{$I^{2}(\%)$} & \multicolumn{3}{|c|}{ Effect of region } & \multirow[b]{2}{*}{ References } \\
\hline Theme & & & & lower & upper & & $Q$ & $p$ & $k$ & \\
\hline know about taking medications & 1 & 100 & 44 & 34.6 & 53.8 & - & - & - & - & (Jin et al., 2006) \\
\hline therapeutic effects of the medication & 1 & 120 & 15.8 & 10.3 & 23.5 & - & - & - & - & (Tang et al., 2015a) \\
\hline
\end{tabular}

This article is protected by copyright. All rights reserved. 


\section{side effects of the medication}

long-term use of medications will not cause addiction one should not increase or decrease the dose without permission

length of duration for keeping the patient on medications

importance of medicine adherence

\section{one should not take medications intermittently}

one should not stop taking medications on his/her own decision

know about treatment for first-episode schizophrenia

know about psychoeducational interventions

regular exercise is helpful

importance of regular follow-up

\section{know about the signs of recovery}

know about how to improve the patient's self-care ability know about how to help the patient return to society

Knowledge of treatment - severe mental illnesses

know about available treatment

things one should pay attention to after the onset of the illness

treatment that the patient has received

name of the medication that the patient is taking

therapeutic effects of the medication

side effects of the medication

know about how to cope with the side effects

\begin{tabular}{|c|c|c|c|c|c|c|c|c|c|}
\hline 6 & 839 & 20 & 13.2 & 29.2 & 86.2 & 1.73 & .189 & $\begin{array}{l}2 \mathrm{~N} \\
4 \mathrm{~S}\end{array}$ & $\begin{array}{l}\text { (Chen et al., 2008; Qu et al., 2014; Ran } \\
\text { et al., 2003; Tang et al., 2015a; Xing et } \\
\text { al., 2002; Yu et al., 2006) }\end{array}$ \\
\hline 1 & 458 & 36.2 & 32 & 40.7 & - & - & - & - & (Ding \& Chen, 2012) \\
\hline & 844 & 71.3 & 25.2 & 94.8 & 99.2 & $\begin{array}{l}129 . \\
13\end{array}$ & $\begin{array}{l}<.00 \\
1\end{array}$ & $\begin{array}{l}1 \mathrm{~N} \\
1 \mathrm{~S}\end{array}$ & (Ding \& Chen, 2012; Jiao et al., 2017) \\
\hline & 300 & 19 & 15 & 23.8 & - & - & - & - & (Qu et al., 2014) \\
\hline & 1,219 & 41.7 & 23.6 & 62.4 & 97.3 & 1.10 & .294 & $\begin{array}{l}2 \mathrm{~N} \\
3 \mathrm{~S}\end{array}$ & $\begin{array}{l}\text { (Chen et al., 2008; Ding \& Chen, 2012; } \\
\text { Jiao et al., 2017; Ran et al., 2003; Yu et } \\
\text { al., 2006) }\end{array}$ \\
\hline & 386 & 80.9 & 76.7 & 84.5 & - & - & - & - & (Jiao et al., 2017) \\
\hline & 386 & 73 & 68.4 & 77.2 & - & - & - & - & (Jiao et al., 2017) \\
\hline & 44 & 4.6 & 1.1 & 16.4 & - & - & - & - & (Xing et al., 2002) \\
\hline & 100 & 44 & 34.6 & 53.8 & - & - & - & - & (Jin et al., 2006) \\
\hline & 458 & 85.6 & 82.1 & 88.5 & - & - & - & - & (Ding \& Chen, 2012) \\
\hline & 586 & 37.5 & 0.4 & 98.8 & 99.5 & $\begin{array}{l}181 . \\
75\end{array}$ & $\begin{array}{l}<.00 \\
1\end{array}$ & $\begin{array}{l}1 \mathrm{~N} \\
1 \mathrm{~S}\end{array}$ & (Chen et al., 2008; Jiao et al., 2017) \\
\hline & 244 & 7.1 & 0.9 & 38.8 & 92.3 & 0.03 & .868 & $\begin{array}{l}1 \mathrm{~N} \\
1 \mathrm{~S}\end{array}$ & (Li et al., 2018; Xing et al., 2002) \\
\hline & 100 & 47 & 37.5 & 56.8 & - & - & - & - & (Yu et al., 2006) \\
\hline & 500 & 11.6 & 5.9 & 21.6 & 83.9 & - & - & $2 \mathrm{~S}$ & (Chen et al., 2008; Qu et al., 2014) \\
\hline & 150 & 52.7 & 44.7 & 60.5 & - & - & - & - & (Huang, 2013) \\
\hline & 292 & 32.5 & 27.4 & 38.1 & - & - & - & - & (Li \& Zhao, 2018) \\
\hline & 292 & 54.1 & 48.4 & 59.7 & - & - & - & - & (Li \& Zhao, 2018) \\
\hline & 538 & 25.8 & 7.1 & 61.2 & 98.0 & 4.75 & .029 & $\begin{array}{l}1 \mathrm{~N} \\
1 \mathrm{~S}\end{array}$ & (Li \& Zhao, 2018; Lou, 2013) \\
\hline & 292 & 34.9 & 29.7 & 40.6 & - & - & - & - & (Li \& Zhao, 2018) \\
\hline & 442 & 30.3 & 12.6 & 56.7 & 96.2 & $\begin{array}{l}26.0 \\
8\end{array}$ & $\begin{array}{l}<.00 \\
1\end{array}$ & $\begin{array}{l}1 \mathrm{~N} \\
1 \mathrm{~S}\end{array}$ & (Huang, 2013; Li \& Zhao, 2018) \\
\hline & 150 & 46 & 38.2 & 54 & - & - & - & - & (Huang, 2013) \\
\hline
\end{tabular}

This article is protected by copyright. All rights reserved. 


\begin{tabular}{|c|c|c|c|c|c|c|c|c|c|c|}
\hline \multirow{2}{*}{$\overline{2}$} & \multirow[b]{2}{*}{$k$} & \multirow[b]{2}{*}{$N$} & \multirow[b]{2}{*}{$\begin{array}{l}\text { Rate } \\
(\%)\end{array}$} & \multicolumn{2}{|c|}{ 95\%CI (\%) } & \multirow[b]{2}{*}{$I^{2}(\%)$} & \multicolumn{3}{|c|}{ Effect of region } & \multirow[b]{2}{*}{ References } \\
\hline & & & & lower & upper & & $Q$ & $p$ & $k$ & \\
\hline importance of medicine adherence & 2 & 442 & 51.6 & 39.8 & 63.2 & 82.7 & 1.6 & .205 & $\begin{array}{l}1 \mathrm{~N} \\
1 \mathrm{~S}\end{array}$ & (Huang, 2013; Li \& Zhao, 2018) \\
\hline importance of regular follow-up & 2 & 1,088 & 55.7 & 12 & 92.1 & 99.5 & 1.0 & .318 & $\begin{array}{l}1 \mathrm{~N} \\
1 \mathrm{~S}\end{array}$ & (Li \& Zhao, 2018; Yang et al., 2018) \\
\hline know about the signs of recovery & 1 & 150 & 26 & 19.6 & 33.6 & - & - & - & - & (Huang, 2013) \\
\hline $\begin{array}{l}\text { know about rehabilitation for severe mental illnesses } \\
\text { Knowledge of treatment - depression or anxiety }\end{array}$ & 1 & 150 & 64.7 & 56.7 & 71.9 & - & - & - & - & (Huang, 2013) \\
\hline know about available treatment & 1 & 200 & 26.5 & 20.8 & 33 & - & - & - & - & (Xing \& Kang, 2017) \\
\hline know about medical treatment & 1 & 200 & 9 & 5.7 & 13.8 & - & - & - & - & (Xing \& Kang, 2017) \\
\hline know about side effects of the medication and how to cope with them & 1 & 200 & 9.5 & 6.1 & 14.4 & - & - & - & - & (Xing \& Kang, 2017) \\
\hline know about effects of psychotherapy & 1 & 200 & 44 & 37.3 & 51 & - & - & - & - & (Xing \& Kang, 2017) \\
\hline Knowledge of treatment - ECT & & & & & & & & & & \\
\hline ECT is safe & 2 & 328 & 68.9 & 58.5 & 77.6 & 69.7 & - & - & $2 \mathrm{~N}$ & (Li et al., 2016; Zhang et al., 2018) \\
\hline ECT does not generate fear & 2 & 328 & 54.2 & 47.5 & 60.7 & 30.8 & - & - & $2 \mathrm{~N}$ & (Li et al., 2016; Zhang et al., 2018) \\
\hline I do not think ECT is more dangerous than drugs & 2 & 328 & 48.1 & 42.7 & 53.5 & 0 & - & - & $2 \mathrm{~N}$ & (Li et al., 2016; Zhang et al., 2018) \\
\hline ECT is not dangerous and should be used & 2 & 328 & 69.7 & 39.7 & 88.9 & 95.4 & - & - & $2 \mathrm{~N}$ & (Li et al., 2016; Zhang et al., 2018) \\
\hline ECT is used for people who need it (e.g., critically ill patients) & 2 & 328 & 45 & 32.2 & 58.6 & 82.7 & - & - & $2 \mathrm{~N}$ & (Li et al., 2016; Zhang et al., 2018) \\
\hline ECT should not be the last resort & 2 & 328 & 37.2 & 29.9 & 45.1 & 50.6 & - & - & $2 \mathrm{~N}$ & (Li et al., 2016; Zhang et al., 2018) \\
\hline $\begin{array}{l}\text { ECT is not used to punish patients } \\
\text { Knowledge of treatment - medication }\end{array}$ & 2 & 328 & 78.6 & 73.8 & 82.7 & 0 & - & - & $2 \mathrm{~N}$ & (Li et al., 2016; Zhang et al., 2018) \\
\hline medications should be taken regularly & 2 & 551 & 69.5 & 65.5 & 73.2 & 0 & - & - & $2 S$ & (Zhang et al., 2014; Zhu et al., 2018) \\
\hline $\begin{array}{l}\text { know about antipsychotic medications } \\
\text { Knowledge of treatment - available services }\end{array}$ & 1 & 804 & 35.1 & 31.9 & 38.5 & - & - & - & - & (Chen \& Tan, 2010) \\
\hline patients can get free medical treatment & 2 & 864 & 86.7 & 52.6 & 97.4 & 94.4 & $\begin{array}{l}17.7 \\
9\end{array}$ & $\begin{array}{l}<.00 \\
1\end{array}$ & $\begin{array}{l}1 \mathrm{~N} \\
1 \mathrm{~S}\end{array}$ & (Tang et al., 2016; Zhang et al., 2010) \\
\hline patients can get free health check-up in community health services & 1 & 107 & 89.7 & 82.4 & 94.2 & - & - & - & - & (Tang et al., 2016) \\
\hline
\end{tabular}


patients can participate in rehabilitation training patients can live in community rehabilitation institutions

know what community services are free to patients

Knowledge of family involvement - schizophrenia

family involvement is important in the process of recovery

family members' negative attitudes can influence patients' conditions

know about how to involve in the treatment

know about skills and methods of coping with the illness at home Table 4

$\begin{array}{llllllllll}1 & 107 & 25.2 & 17.9 & 34.3 & - & - & - & - & \text { (Tang et al., 2016) } \\ 1 & 107 & 9.4 & 5.1 & 16.6 & - & - & - & - & \text { (Tang et al., 2016) } \\ 1 & 796 & 69.3 & 66.1 & 72.5 & - & - & - & - & \text { (Yang et al., 2018) } \\ & & & & & & & & & \\ 1 & 458 & 50.4 & 45.9 & 55 & - & - & - & - & \text { (Ding \& Chen, 2012) } \\ 1 & 386 & 52.5 & 47.5 & 57.4 & - & - & - & - & \text { (Jiao et al., 2017) } \\ 1 & 200 & 2 & 0.8 & 5.2 & - & - & - & - & \text { (Li et al., 2018) } \\ 1 & 200 & 0 & - & - & - & - & - & - & \text { (Li et al., 2018) }\end{array}$

Continued

\begin{tabular}{|c|c|c|c|c|c|c|c|c|c|c|}
\hline \multirow{2}{*}{ Theme } & \multirow[b]{2}{*}{$k$} & \multirow[b]{2}{*}{$N$} & \multirow[b]{2}{*}{$\begin{array}{l}\text { Rate } \\
(\%)\end{array}$} & \multicolumn{2}{|c|}{ 95\%CI (\%) } & \multirow[b]{2}{*}{$I^{2}(\%)$} & \multicolumn{3}{|c|}{ Effect of region } & \multirow[b]{2}{*}{ References } \\
\hline & & & & lower & upper & & $Q$ & $p$ & $k$ & \\
\hline know about how to provide care at home & 1 & 120 & 17.5 & 11.7 & 25.4 & - & - & - & - & (Tang et al., 2015a) \\
\hline know about how to keep the patient safe & 1 & 100 & 21 & 14.1 & 30.1 & - & - & - & - & (Yu et al., 2006) \\
\hline know about how to provide healthy diet & 1 & 100 & 49 & 39.4 & 58.7 & - & - & - & - & (Yu et al., 2006) \\
\hline know about family involvement in medication administration & 2 & 500 & 33.3 & 11.4 & 66.1 & 97.9 & - & - & $2 S$ & (Li et al., 2018; Qu et al., 2014) \\
\hline know about the precautions of taking medications during pregnancy & 1 & 300 & 9.3 & 6.5 & 13.1 & - & - & - & - & (Qu et al., 2014) \\
\hline know about how to communicate with the patient & 2 & 400 & 24.9 & 9.9 & 50 & 94.7 & 0.02 & .880 & $\begin{array}{l}1 \mathrm{~N} \\
1 \mathrm{~S}\end{array}$ & (Qu et al., 2014; Yu et al., 2006) \\
\hline psychological support is important for recovery & 1 & 458 & 46.1 & 41.6 & 50.7 & - & - & - & - & (Ding \& Chen, 2012) \\
\hline keeping contact with the doctor & 2 & 486 & 62.6 & 44.5 & 77.7 & 90.7 & $\begin{array}{l}10.7 \\
2\end{array}$ & .001 & $\begin{array}{l}1 \mathrm{~N} \\
1 \mathrm{~S}\end{array}$ & (Jiao et al., 2017; Jin et al., 2006) \\
\hline $\begin{array}{l}\text { Knowledge of family involvement - severe mental illnesses } \\
\text { importance of family involvement in the treatment }\end{array}$ & 1 & 150 & 68 & 60.1 & 75 & - & - & - & - & (Huang, 2013) \\
\hline know about how to provide care at home & 2 & 538 & 18 & 7.3 & 37.8 & 94.7 & $\begin{array}{l}18.7 \\
7\end{array}$ & $\begin{array}{l}<.00 \\
1\end{array}$ & $\begin{array}{l}1 \mathrm{~N} \\
1 \mathrm{~S}\end{array}$ & (Li \& Zhao, 2018; Lou, 2013) \\
\hline things one should pay attention to when taking care of the patient & 1 & 292 & 30.5 & 25.5 & 36 & - & - & - & - & (Li \& Zhao, 2018) \\
\hline know about family involvement in medication administration & 2 & 1,088 & 63.4 & 13.1 & 95.3 & 99.6 & $\begin{array}{l}242 . \\
2\end{array}$ & $\begin{array}{l}<.00 \\
1\end{array}$ & $\begin{array}{l}1 \mathrm{~N} \\
1 \mathrm{~S}\end{array}$ & (Li \& Zhao, 2018; Yang et al., 2018) \\
\hline cooperating with community health professionals for follow-up care & 1 & 796 & 92.3 & 90.3 & 94 & - & - & - & - & (Yang et al., 2018) \\
\hline
\end{tabular}


Knowledge of family involvement - mental illness in general

family should involve in the treatment

importance of family involvement

know about how to take care of the patient

$\begin{array}{lllllllll}2 & 869 & 30.3 & 14.1 & 53.5 & 93.9 & 16.4 & <.00 & 1 \mathrm{~N}\end{array}$

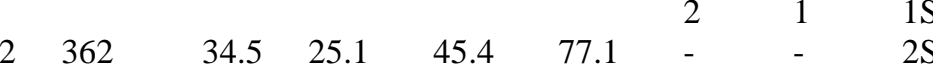

$\begin{array}{lllllllll}7 & 1,132 & 24.9 & 14.8 & 38.9 & 94.8 & - & - & 7 S\end{array}$

things one should pay attention to after discharge

2226

40.6

31.150 .9

58.7

if a family member has a mental health issue, I will accompany him/her to $\quad 1 \quad 757$ see a doctor

how to ensure that the patient takes medications as prescribed

116

$81.4 \quad 78.4 \quad 84$

$-$

$\begin{array}{llll}35.3 & 27.2 & 44.4 \quad-\end{array}$

$20.7 \quad 16.4$

25.9

\section{Table 4}

Continued

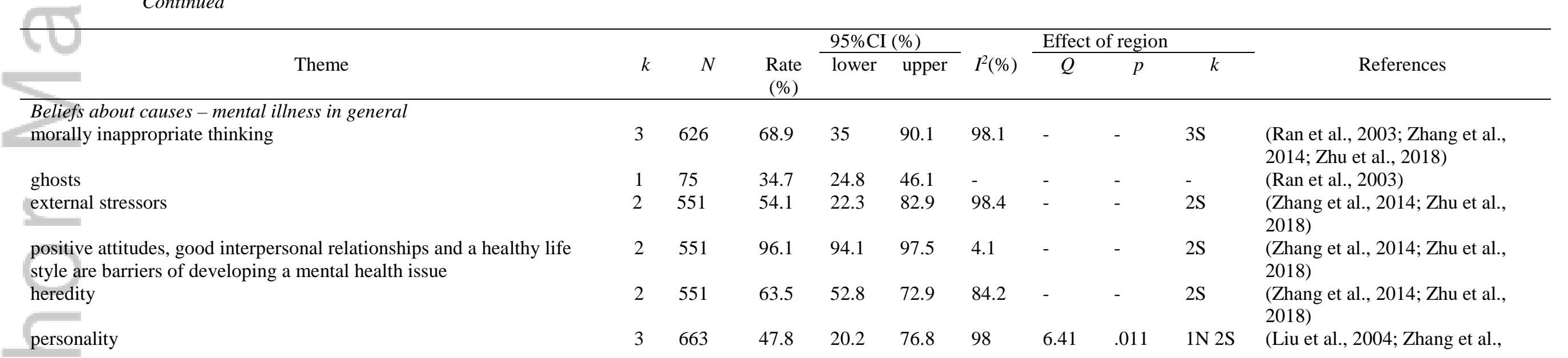

This article is protected by copyright. All rights reserved. 


\section{negative life events}

a combination of genetics, family environment, organic damage, personality and negative life events

Beliefs about causes - schizophrenia virus of infection

allergy

daily problems

work or financial problems

poor interpersonal relationship

death of someone else

recently traumatic event

negative childhood experience

heredity

chemical imbalance in the brain or abnormal brain structure

nervous person

weakness of character introversion

\begin{tabular}{|c|c|c|c|c|c|c|c|c|c|}
\hline 2 & 551 & 95.5 & 63.2 & 99.6 & 94.5 & - & - & $2 S$ & $\begin{array}{l}\text { 2014; Zhu et al., 2018) } \\
\text { (Zhang et al., 2014; Zhu et al., } \\
\text { 2018) }\end{array}$ \\
\hline 1 & 757 & 64.2 & 60.7 & 67.5 & - & - & - & - & (Zhang et al., 2010) \\
\hline 2 & 586 & 10.1 & 4.5 & 21.4 & 90.0 & 10.0 & .002 & $1 \mathrm{~N} 1 \mathrm{~S}$ & $\begin{array}{l}\text { (Chen et al., 2017; Jiao et al., } \\
\text { 2017) }\end{array}$ \\
\hline 1 & 200 & 17.5 & 12.8 & 23.4 & - & - & - & - & (Chen et al., 2017) \\
\hline 1 & 200 & 81.5 & 75.5 & 86.3 & - & - & - & - & (Chen et al., 2017) \\
\hline 1 & 200 & 82 & 76.1 & 86.7 & - & - & - & - & (Chen et al., 2017) \\
\hline 1 & 386 & 57.9 & 52.9 & 62.7 & - & - & - & - & (Jiao et al., 2017) \\
\hline 1 & 200 & 50 & 43.1 & 56.9 & - & - & - & - & (Chen et al., 2017) \\
\hline 1 & 200 & 64.5 & 57.6 & 70.8 & - & - & - & - & (Chen et al., 2017) \\
\hline 2 & 586 & 37.7 & 17.4 & 63.5 & 97.1 & 0.39 & .530 & $1 \mathrm{~N} 1 \mathrm{~S}$ & $\begin{array}{l}\text { (Chen et al., 2017; Jiao et al., } \\
\text { 2017) }\end{array}$ \\
\hline 3 & 706 & 37 & 20.8 & 56.8 & 95.7 & 46.4 & $<.001$ & $1 \mathrm{~N} 2 \mathrm{~S}$ & $\begin{array}{l}\text { (Chen et al., 2017; Jiao et al., } \\
\text { 2017; Tang et al., 2015a) }\end{array}$ \\
\hline 2 & 586 & 47 & 40.1 & 54.1 & 63.4 & 2.73 & .098 & $1 \mathrm{~N} 1 \mathrm{~S}$ & $\begin{array}{l}\text { (Chen et al., 2017; Jiao et al., } \\
\text { 2017) }\end{array}$ \\
\hline 1 & 200 & 59.5 & 52.6 & 66.1 & - & - & - & - & (Chen et al., 2017) \\
\hline 1 & 200 & 72.5 & 65.9 & 78.2 & - & - & - & - & (Chen et al., 2017) \\
\hline 1 & 386 & 84 & 80 & 87.3 & - & - & - & - & (Jiao et al., 2017) \\
\hline
\end{tabular}

Table 4

Continued

\begin{tabular}{|c|c|c|c|c|c|c|c|c|c|c|c|}
\hline \multirow{2}{*}{$x$} & \multirow[b]{2}{*}{ Theme } & \multirow[b]{2}{*}{$k$} & \multirow[b]{2}{*}{$N$} & \multirow[b]{2}{*}{ Rate (\%) } & \multicolumn{2}{|c|}{ 95\%CI (\%) } & \multirow[b]{2}{*}{$I^{2}(\%)$} & \multicolumn{3}{|c|}{ Effect of region } & \multirow[b]{2}{*}{ References } \\
\hline & & & & & lower & upper & & $Q$ & $p$ & $k$ & \\
\hline & & 2 & 506 & 91.7 & 74.9 & 97.6 & 93 & 14.23 & $<.001$ & $1 \mathrm{~N} 1 \mathrm{~S}$ & $\begin{array}{l}\text { (Jiao et al., 2017; Tang et al., } \\
\text { 2015a) }\end{array}$ \\
\hline overthi & & 1 & 120 & 70.8 & 62.1 & 78.2 & - & - & - & - & (Tang et al., 2015a) \\
\hline family & & 2 & 506 & 69.7 & 31.5 & 92 & 97.3 & 37.1 & $<.001$ & $1 \mathrm{~N} 1 \mathrm{~S}$ & (Jiao et al., 2017; Tang et al., \\
\hline
\end{tabular}


physical and intellectual development issue

substance use

physical health issues (e.g., abnormal body structure)

ghosts

Beliefs about causes - depression

virus of infection

allergy

daily problems

work or financial problems

death of someone else

recently traumatic event

negative childhood experience

heredity

chemical imbalance in the brain

nervous person

weakness of character

Beliefs about treatment-medication

counseling alone is not enough, patients should also take medicine

long-term use of psychiatric medications will not make the patient less

intelligent

Beliefs about treatment - ECT

ECT is beneficial

ECT is more effective than drugs

the effect of ECT is more rapid than drugs

would like to let my relative receive ECT again

$\begin{array}{lll}1 & 386 & 15 . \\ 1 & 386 & 22 . \\ 2 & 506 & 62 . \\ & & \\ 1 & 386 & 39.9 \\ & & \\ 1 & 202 & 15 . \\ 1 & 202 & 22 . \\ 1 & 202 & 79.2 \\ 1 & 202 & 80.2 \\ 1 & 202 & 66 . \\ 1 & 202 & 72 . \\ 1 & 202 & 51 . \\ 1 & 202 & 51 \\ 1 & 202 & 52 \\ 1 & 202 & 60.9 \\ 1 & 202 & 68.3 \\ & & \\ 1 & 79 & 83 . \\ 1 & 112 & 8\end{array}$

$2 \quad 328 \quad 75.3$

$2 \quad 328 \quad 63.6$

$\begin{array}{lll}2 & 328 & 70.8\end{array}$

$2 \quad 328 \quad 65.1$

\begin{tabular}{|c|c|c|c|c|c|}
\hline & & & & & 2015a) \\
\hline 19.4 & - & - & - & - & (Jiao et al., 2017) \\
\hline 26.5 & - & - & - & - & (Jiao et al., 2017) \\
\hline 69.8 & 55.1 & 2.23 & .136 & $1 \mathrm{~N} 1 \mathrm{~S}$ & $\begin{array}{l}\text { (Jiao et al., 2017; Tang et al., } \\
\text { 2015a) }\end{array}$ \\
\hline 44.9 & - & - & - & - & (Jiao et al., 2017) \\
\hline 21.5 & - & - & - & - & (Chen et al., 2017) \\
\hline 28.6 & - & - & - & - & (Chen et al., 2017) \\
\hline 84.2 & - & - & - & - & (Chen et al., 2017) \\
\hline 85.1 & - & - & - & - & (Chen et al., 2017) \\
\hline 72.9 & - & - & - & - & (Chen et al., 2017) \\
\hline 65.7 & - & - & - & - & (Chen et al., 2017) \\
\hline 58.3 & - & - & - & - & (Chen et al., 2017) \\
\hline 57.8 & - & - & - & - & (Chen et al., 2017) \\
\hline 58.8 & - & - & - & - & (Chen et al., 2017) \\
\hline 67.4 & - & - & - & - & (Chen et al., 2017) \\
\hline 74.3 & - & - & - & - & (Chen et al., 2017) \\
\hline 90.2 & - & - & - & - & (Gao et al., 2004) \\
\hline 14.7 & - & - & - & - & (Liu et al., 2004) \\
\hline 82.1 & 57.5 & - & - & $2 \mathrm{~N}$ & $\begin{array}{l}\text { (Li et al., 2016; Zhang et al., } \\
\text { 2018) }\end{array}$ \\
\hline 68.6 & 0 & - & - & $2 \mathrm{~N}$ & $\begin{array}{l}\text { (Li et al., 2016; Zhang et al., } \\
\text { 2018) }\end{array}$ \\
\hline 75.4 & 0 & - & - & $2 \mathrm{~N}$ & $\begin{array}{l}\text { (Li et al., 2016; Zhang et al., } \\
\text { 2018) }\end{array}$ \\
\hline 74.1 & 68.7 & - & - & $2 \mathrm{~N}$ & $\begin{array}{l}\text { (Li et al., 2016; Zhang et al., } \\
\text { 2018) }\end{array}$ \\
\hline
\end{tabular}

This article is protected by copyright. All rights reserved. 


\begin{tabular}{|c|c|c|c|c|c|c|c|c|c|c|}
\hline \multirow[b]{2}{*}{ Theme } & \multirow[b]{2}{*}{$k$} & \multirow[b]{2}{*}{$N$} & \multirow[b]{2}{*}{$\begin{array}{c}\text { Rate } \\
(\%)\end{array}$} & \multicolumn{2}{|c|}{ 95\%CI (\%) } & \multirow[b]{2}{*}{$I^{2}(\%)$} & \multicolumn{3}{|c|}{ Effect of region } & \multirow[b]{2}{*}{ References } \\
\hline & & & & lower & upper & & $Q$ & $p$ & $k$ & \\
\hline \multicolumn{11}{|c|}{ Beliefs about treatment - schizophrenia (professionals) } \\
\hline GP or family doctor & 1 & 200 & 62.5 & 55.6 & 68.9 & - & - & - & - & (Chen et al., 2017) \\
\hline pharmacist & 1 & 200 & 40.5 & 33.9 & 47.4 & - & - & - & - & (Chen et al., 2017) \\
\hline counselor & 1 & 200 & 74 & 67.5 & 79.6 & - & - & - & - & (Chen et al., 2017) \\
\hline social worker & 1 & 200 & 46 & 39.2 & 52.9 & - & - & - & - & (Chen et al., 2017) \\
\hline telephone counseling service & 1 & 200 & 46 & 39.2 & 52.9 & - & - & - & - & (Chen et al., 2017) \\
\hline psychiatrist & 1 & 200 & 97 & 93.5 & 98.6 & - & - & - & - & (Chen et al., 2017) \\
\hline mental health nurse & 1 & 200 & 89 & 83.9 & 92.6 & - & - & - & - & (Chen et al., 2017) \\
\hline psychologist & 1 & 200 & 96 & 92.2 & 98 & - & - & - & - & (Chen et al., 2017) \\
\hline close family members & 1 & 200 & 92.5 & 87.9 & 95.4 & - & - & - & - & (Chen et al., 2017) \\
\hline close friends & 1 & 200 & 87.5 & 82.2 & 91.4 & - & - & - & - & (Chen et al., 2017) \\
\hline traditional healer/Chinese medicine doctor & 1 & 200 & 52.5 & 45.6 & 59.3 & - & - & - & - & (Chen et al., 2017) \\
\hline dealing with problem on his/her own & 1 & 200 & 11.5 & 7.8 & 16.7 & - & - & - & - & (Chen et al., 2017) \\
\hline religious leader & 1 & 200 & 7 & 4.2 & 11.5 & - & - & - & - & (Chen et al., 2017) \\
\hline \multicolumn{11}{|c|}{ Beliefs about treatment - schizophrenia (interventions) } \\
\hline becoming more physically active & 2 & 586 & 78.9 & 16.2 & 98.6 & 98.8 & 2.15 & .143 & $1 \mathrm{~N} 1 \mathrm{~S}$ & (Chen et al., 2017; Jiao et al., 2017) \\
\hline reading about the problem & 1 & 200 & 64 & 57.1 & 70.4 & - & - & - & - & (Chen et al., 2017) \\
\hline getting out and learning more & 1 & 200 & 93 & 88.5 & 95.8 & - & - & - & - & (Chen et al., 2017) \\
\hline being kept at home & 1 & 200 & 18 & 13.3 & 23.9 & - & - & - & - & (Chen et al., 2017) \\
\hline attending courses on relaxation & 1 & 200 & 76.5 & 70.1 & 81.9 & - & - & - & - & (Chen et al., 2017) \\
\hline massage and having a rest & 1 & 200 & 69.5 & 62.8 & 75.5 & - & - & - & - & (Chen et al., 2017) \\
\hline cutting out alcohol & 1 & 200 & 83 & 77.1 & 87.6 & - & - & - & - & (Chen et al., 2017) \\
\hline having occasional drink & 1 & 200 & 11.5 & 7.8 & 16.7 & - & - & - & - & (Chen et al., 2017) \\
\hline practicing Chi Kung/Tai Chi therapy & 1 & 200 & 42.5 & 35.8 & 49.5 & - & - & - & - & (Chen et al., 2017) \\
\hline receiving acupuncture & 1 & 200 & 35 & 28.7 & 41.9 & - & - & - & - & (Chen et al., 2017) \\
\hline receiving psychotherapy & 1 & 200 & 94 & 89.7 & 96.6 & - & - & - & - & (Chen et al., 2017) \\
\hline participating in hypnosis & 1 & 200 & 56 & 49 & 62.7 & - & - & - & - & (Chen et al., 2017) \\
\hline receiving aromatherapy & 1 & 200 & 26.5 & 20.8 & 33 & - & - & - & - & (Chen et al., 2017) \\
\hline
\end{tabular}


receiving rehabilitation training

being admitted to a psychiatric ward in a general hospital

being admitted to a psychiatric hospital

receiving ECT

going on a special diet

living with family members Table 4

$\begin{array}{lllllllll}386 & 14.7 & 11.5 & 18.6 & - & - & - & - & \text { (Jiao et al., 2017) } \\ 200 & 81 & 75 & 85.9 & - & - & - & - & \text { (Chen et al., 2017) } \\ 200 & 70 & 63.3 & 75.9 & - & - & - & - & \text { (Chen et al., 2017) } \\ 200 & 25.5 & 19.9 & 32 & - & - & - & - & \text { (Chen et al., 2017) } \\ 200 & 45.5 & 38.7 & 52.4 & - & - & - & - & \text { (Chen et al., 2017) } \\ 386 & 53.4 & 48.4 & 58.3 & - & - & - & - & \text { (Jiao et al., 2017) }\end{array}$

(Jiao et al., 2017)

\section{Continued}

\begin{tabular}{|c|c|c|c|c|c|c|c|c|c|c|}
\hline \multirow[b]{2}{*}{ Theme } & \multirow[b]{2}{*}{$k$} & \multirow[b]{2}{*}{$N$} & \multirow[b]{2}{*}{$\begin{array}{c}\text { Rate } \\
(\%)\end{array}$} & \multicolumn{2}{|c|}{ 95\%CI (\%) } & \multirow[b]{2}{*}{$I^{2}(\%)$} & \multicolumn{3}{|c|}{ Effect of region } & \multirow[b]{2}{*}{ References } \\
\hline & & & & lower & upper & & $Q$ & $p$ & $k$ & \\
\hline actively engaging in the communication with family members & 1 & 386 & 51.3 & 46.3 & 56.3 & - & - & - & - & (Jiao et al., 2017) \\
\hline doing simple housework & 1 & 386 & 54.6 & 49.6 & 59.5 & - & - & - & - & (Jiao et al., 2017) \\
\hline keeping contact with friends and relatives & 1 & 386 & 54.5 & 49.5 & 59.4 & - & - & - & - & (Jiao et al., 2017) \\
\hline keeping contact with mental health professionals & 1 & 386 & 35.8 & 31.2 & 40.7 & - & - & - & - & (Jiao et al., 2017) \\
\hline \multicolumn{11}{|l|}{ Beliefs about treatment - schizophrenia (medications) } \\
\hline vitamins and minerals & 1 & 200 & 40.5 & 33.9 & 47.4 & - & - & - & - & (Chen et al., 2017) \\
\hline laxatives & 1 & 200 & 14 & 9.8 & 19.5 & - & - & - & - & (Chen et al., 2017) \\
\hline herbal medicines & 1 & 200 & 36 & 29.6 & 42.9 & - & - & - & - & (Chen et al., 2017) \\
\hline pain relievers & 1 & 200 & 11 & 7.4 & 16.1 & - & - & - & - & (Chen et al., 2017) \\
\hline antidepressants & 1 & 200 & 78.5 & 72.3 & 83.6 & - & - & - & - & (Chen et al., 2017) \\
\hline antibiotics & 1 & 200 & 17 & 12.4 & 22.9 & - & - & - & - & (Chen et al., 2017) \\
\hline sleeping pills & 1 & 200 & 30 & 24.1 & 36.7 & - & - & - & - & (Chen et al., 2017) \\
\hline antipsychotics & 1 & 200 & 82 & 76.1 & 86.7 & - & - & - & - & (Chen et al., 2017) \\
\hline tranquillizers & 1 & 200 & 52 & 45.1 & 58.8 & - & - & - & - & (Chen et al., 2017) \\
\hline anti-anxiety drugs & 1 & 200 & 77 & 70.7 & 82.3 & - & - & - & - & (Chen et al., 2017) \\
\hline medical treatment & 1 & 386 & 86.7 & 82.9 & 89.7 & - & - & - & - & (Jiao et al., 2017) \\
\hline \multicolumn{11}{|l|}{ Beliefs about treatment - depression (professionals) } \\
\hline GP or family doctor & 1 & 202 & 69.3 & 62.6 & 75.3 & - & - & - & - & (Chen et al., 2017) \\
\hline pharmacist & 1 & 202 & 40.1 & 33.6 & 47 & - & - & - & - & (Chen et al., 2017) \\
\hline counselor & 1 & 202 & 71.3 & 64.7 & 77.1 & - & - & - & - & (Chen et al., 2017) \\
\hline
\end{tabular}

This article is protected by copyright. All rights reserved. 
social worker

telephone counseling service

psychiatrist

mental health nurse

psychologist

close family members

close friends

traditional healer/Chinese medicine doctor

dealing with problem on his/her own

religious leader

$\begin{array}{lllllll}45.5 & 38.8 & 52.4 & - & - & - & - \\ 49.5 & 42.7 & 56.4 & - & - & - & - \\ 91.1 & 86.3 & 94.3 & - & - & - & - \\ 77.7 & 71.4 & 82.9 & - & - & - & - \\ 93.1 & 88.7 & 95.9 & - & - & - & - \\ 87.6 & 82.3 & 91.5 & - & - & - & - \\ 82.7 & 76.9 & 87.3 & - & - & - & - \\ 51 & 44.1 & 57.8 & - & - & - & - \\ 20.8 & 15.8 & 26.9 & - & - & - & - \\ 7.4 & 4.5 & 11.9 & - & - & - & -\end{array}$

(Chen et al., 2017)

(Chen et al., 2017)

(Chen et al., 2017)

(Chen et al., 2017)

(Chen et al., 2017)

(Chen et al., 2017)

(Chen et al., 2017)

(Chen et al., 2017)

(Chen et al., 2017)

(Chen et al., 2017)

Table 4

Continued

\begin{tabular}{|c|c|c|c|c|c|c|c|c|c|c|}
\hline \multirow[b]{2}{*}{ Theme } & \multirow[b]{2}{*}{$k$} & \multirow[b]{2}{*}{$N$} & \multirow[b]{2}{*}{$\begin{array}{c}\text { Rate } \\
(\%)\end{array}$} & \multicolumn{2}{|c|}{ 95\%CI (\%) } & \multirow[b]{2}{*}{$I^{2}(\%)$} & \multicolumn{3}{|c|}{ Effect of region } & \multirow[b]{2}{*}{ References } \\
\hline & & & & lower & upper & & $Q$ & $p$ & $k$ & \\
\hline \multicolumn{11}{|c|}{ Beliefs about treatment - depression (interventions) } \\
\hline becoming more physically active & 1 & 202 & 96 & 92.2 & 98 & - & - & - & - & (Chen et al., 2017) \\
\hline reading about the problem & 1 & 202 & 71.3 & 64.7 & 77.1 & - & - & - & - & (Chen et al., 2017) \\
\hline getting out and learning more & 1 & 202 & 90.1 & 85.2 & 93.5 & - & - & - & - & (Chen et al., 2017) \\
\hline being kept at home & 1 & 202 & 30.2 & 24.3 & 36.9 & - & - & - & - & (Chen et al., 2017) \\
\hline attending courses on relaxation & 1 & 202 & 81.2 & 75.2 & 86 & - & - & - & - & (Chen et al., 2017) \\
\hline massage and having a rest & 1 & 202 & 82.7 & 76.9 & 87.3 & - & - & - & - & (Chen et al., 2017) \\
\hline cutting out alcohol & 1 & 202 & 79.7 & 73.6 & 84.7 & - & - & - & - & (Chen et al., 2017) \\
\hline having occasional drink & 1 & 202 & 22.3 & 17.1 & 28.6 & - & - & - & - & (Chen et al., 2017) \\
\hline practicing Chi Kung/Tai Chi therapy & 1 & 202 & 50.5 & 43.6 & 57.3 & - & - & - & - & (Chen et al., 2017) \\
\hline receiving acupuncture & 1 & 202 & 41.1 & 34.5 & 48 & - & - & - & - & (Chen et al., 2017) \\
\hline receiving psychotherapy & 1 & 202 & 93.6 & 89.3 & 96.3 & - & - & - & - & (Chen et al., 2017) \\
\hline participating in hypnosis & 1 & 202 & 65.3 & 58.5 & 71.5 & - & - & - & - & (Chen et al., 2017) \\
\hline
\end{tabular}

This article is protected by copyright. All rights reserved. 
pharmacist

Chinese medicine doctor

dealing with problem on his/her own

religious leader is harmful

Beliefs about treatment - GAD (interventions)

being kept at home

being admitted to a psychiatric ward in a general hospital

receiving ECT is harmful

reading about the problem

getting out and learning more

attending courses on relaxation

massage and have a rest

having occasional drink

practicing Chi Kung/Tai Chi therapy

receiving acupuncture

participating in hypnosis

Beliefs about treatment - GAD (medications)

antibiotics

laxatives

pain relievers

antidepressants

Chinese medicine is harmful

Help-seeking intention

one should seek help from professional services when having mental

health issues

going to see a psychiatrist is the last resort

\begin{tabular}{|c|c|c|c|c|c|c|c|c|}
\hline 204 & 26 & 20.4 & 32.5 & - & - & - & - & (Chen et al., 2018b) \\
\hline 204 & 37.3 & 30.9 & 44.1 & - & - & - & - & (Chen et al., 2018b) \\
\hline 204 & 13.2 & 9.2 & 18.6 & - & - & - & - & (Chen et al., 2018b) \\
\hline 204 & 75.5 & 69.1 & 80.9 & - & - & - & - & (Chen et al., 2018b) \\
\hline 204 & 21.6 & 16.5 & 27.8 & - & - & - & - & (Chen et al., 2018b) \\
\hline 204 & 54.9 & 48 & 61.6 & - & - & - & - & (Chen et al., 2018b) \\
\hline 204 & 59.3 & 52.4 & 65.8 & - & - & - & - & (Chen et al., 2018b) \\
\hline 204 & 68.6 & 61.9 & 74.6 & - & - & - & - & (Chen et al., 2018b) \\
\hline 204 & 91.7 & 87 & 94.8 & - & - & - & - & (Chen et al., 2018b) \\
\hline 204 & 83.3 & 77.6 & 87.8 & - & - & - & - & (Chen et al., 2018b) \\
\hline 204 & 76 & 69.6 & 81.3 & - & - & - & - & (Chen et al., 2018b) \\
\hline 204 & 18.1 & 13.4 & 24 & - & - & - & - & (Chen et al., 2018b) \\
\hline 204 & 47.1 & 40.3 & 53.9 & - & - & - & - & (Chen et al., 2018b) \\
\hline 204 & 36.3 & 30 & 43.1 & - & - & - & - & (Chen et al., 2018b) \\
\hline 204 & 59.3 & 52.4 & 65.8 & - & - & - & - & (Chen et al., 2018b) \\
\hline 204 & 15.7 & 11.3 & 21.3 & - & - & - & - & (Chen et al., 2018b) \\
\hline 204 & 4.9 & 2.7 & 8.9 & - & - & - & - & (Chen et al., 2018b) \\
\hline 204 & 8.3 & 5.2 & 13 & - & - & - & - & (Chen et al., 2018b) \\
\hline 204 & 71.6 & 65 & 77.4 & - & - & - & - & (Chen et al., 2018b) \\
\hline 204 & 25.5 & 20 & 31.9 & - & - & - & - & (Chen et al., 2018b) \\
\hline 1,308 & 84.4 & 63.3 & 94.5 & 97.6 & - & - & $3 S$ & $\begin{array}{l}\text { (Zhang et al., 2014; Zhang et al., } \\
\text { 2010; Zhu et al., 2018) }\end{array}$ \\
\hline 79 & 32.9 & 23.5 & 43.9 & - & - & - & - & (Gao et al., 2004) \\
\hline
\end{tabular}


knowledge of the illness that the patient has (self-

medicine adherence (reported by

398

$-0.06$

0.14

(Jiao et al., 2017)

caregivers)

Note. FIS = Family Impact Scale; MHKQ = Mental Health Knowledge Questionnaire; PDD = Perceived Devaluation-Discrimination; SCL-90-R = Symptom Checklist-90-Revised. 


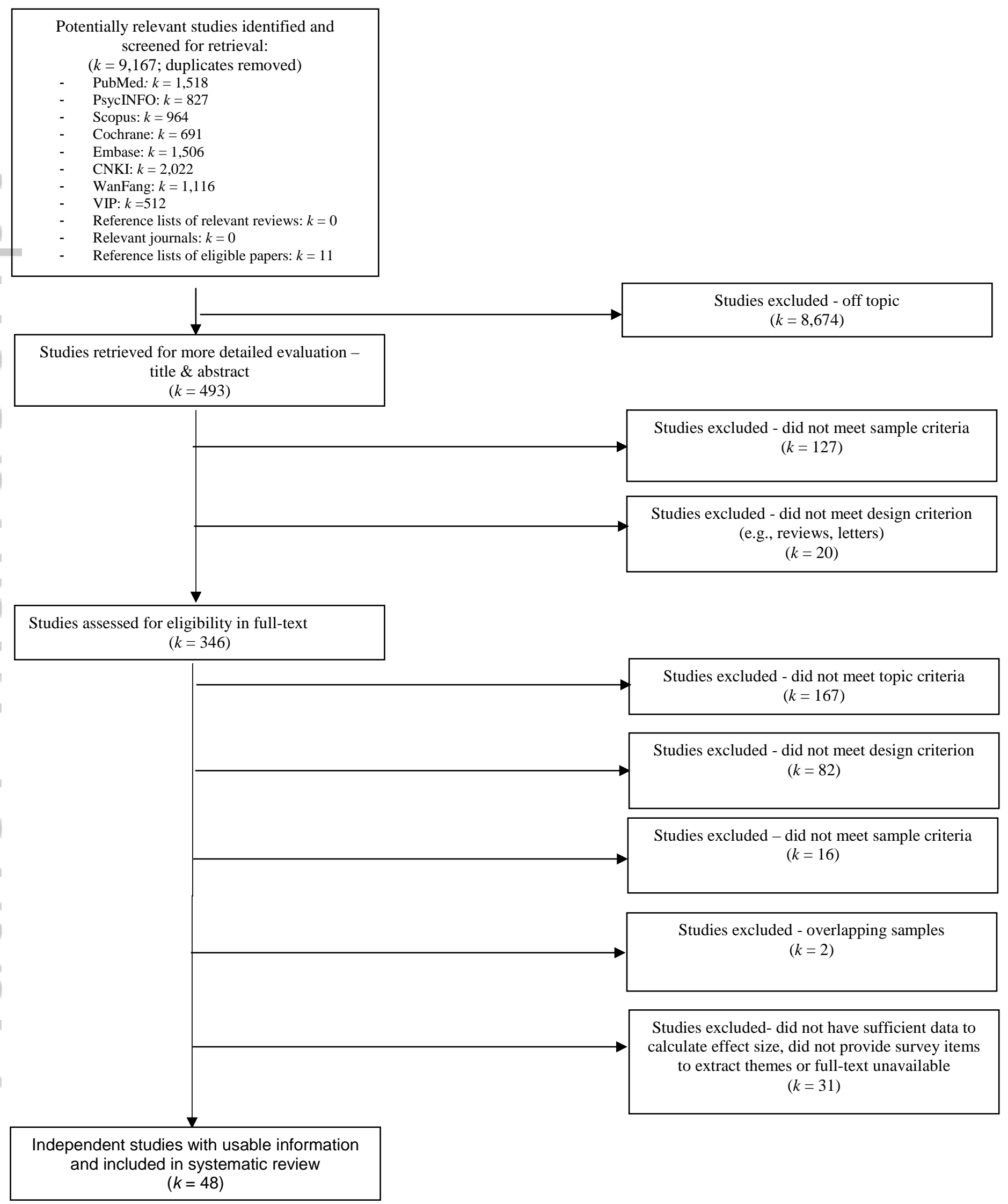

Figure 1. Flow chart of study selection 


\section{University Library}

\section{- M M N E R VA A gateway to Melbourne's research publications}

Minerva Access is the Institutional Repository of The University of Melbourne

Author/s:

Li, W;Reavley, N

Title:

Patients' and caregivers' knowledge and beliefs about mental illness in mainland China: A systematic review

Date:

2020-09-16

\section{Citation:}

Li, W. \& Reavley, N. (2020). Patients' and caregivers' knowledge and beliefs about mental illness in mainland China: A systematic review. ASIA-PACIFIC PSYCHIATRY, 13 (2), https:// doi.org/10.1111/appy.12423.

Persistent Link:

http://hdl.handle.net/11343/276311 